\title{
MANFAAT KEBENARAN PERBUATAN: SUATU ANALISIS TERHADAP AJARAN FILSAFAT PRAGMATISME
}

\author{
Peniel Maiaweng \\ peniel_68@yahoo.com
}

\begin{abstract}
ABSTRAK
Pragmatisme adalah pandangan filsafat yang menekankan bahwa kebenaran adalah manfaat dari sebuah tindakan atau perbuatan. Tokoh-tokoh yang berpengaruh dan yang mengembangkan filsafat pragmatisme adalah Charles Sanders Peirce (1839-19I4), Willian James (1842-1910), John Dewey (1859-1952), dan Richard Rorty (1931-2007). Inti pengaran filsafat pragmatisme adalah, Pertama, Etika bukanlah apa yang benar, tetapi prilaku dan tujuan diri. Kedua, Keyakinan manusia terdapat pada manusia itu sendiri karena menjadi dasar baginya untuk melakukan yang benar, dan keyakinan dimulai dari proposisi yang dinilai benar. Ketiga, Kebenaran adalah relatif karena setiap fakta baru akan memunculkan kebenaran baru yang pengujiannya melalui pembahasan diskusi. Keempat, Kebenaran yang menjadi tuntutan agama dapat ditemukan secara ilmiah. Kelima, Manusia memercayai bahwa kehendaknya yang membebaskannya dari kekasaran, ketakutan, dan kematian, dan manusia harus diperbudak oleh kebebasannya. Keenam, Wahyu adalah mistik, tidak dapat diklaim sebagai kebenaran jika tanpa pengalaman pribadi. Ketujuh, Pengalaman manusia menjadi unsur penting untuk menentukan kebenaran dan metode digunakan untuk mencapai kebenaran yang terdapat dalam pengalaman. Kedelapan, Pengalaman spiritualis dan kesusilaan bukan hasil pembentukan secara keagamaan, tetapi pemberdayaan seluruh potensinya yang direalisasikan dalam masyarakat. Kesembilan, Penyataan bukanlah dari Tuhan, tetapi penemuan yang dilakukan manusia dan kebenaran supernatural tidak diakui karena masalah adikodrati. Kesepuluh, Kesalahan bukanlah dosa, tetapi ketidaksesuaian antara metode dengan akal. Kesebelas, Kebenaran keagamaan bukanlah sesuatu yang diwahyukan, tetapi muncul dari keinginan, dorongan, perasaan dan kebiasaan manusia.
\end{abstract}

Kata Kunci: pragmatisme, tindakan, kebenaran, manfaat, etika, dan wahyu 


\section{PENDAHULUAN}

\section{Kecenderungan Prilaku Manusia Abad XXI yang Pragmatis}

Kecenderungan kehidupan manusia pada abad XXI adalah berpikir praktis (pragmatis) yang didasarkan pada penggunaan tekonologi dan berbagai fasilitas secara negatif, yang dapat mereduksi keberadaan Allah yang transenden. Manusia cenderung menyingkirkan Allah dan mengandalkan kemampuannya sendiri untuk mencapai kepuasan hidup. ${ }^{1}$ Sadar atau tidak, kecenderungan kehidupan manusia saat ini adalah menjalani kehidupan secara praktis, yang konkrit, terukur, jelas penggunaannya, ${ }^{2}$ dan memberikan manfaat bagi manusia baik secara pribadi maupun secara umum. Jika hal-hal demikian telah dialami seseorang, maka sudah cukup baginya untuk hidup. Ia tidak perlu lagi memikirkan siapa Penciptanya dan nilai spiritual tidak menjadi prioritas dalam hidupnya. Cara hidup demikian menunjukkan bahwa pragmatisme sedang menjadi bagian kehidupan manusia abad XXI.

\section{Mungkinkah Perbuatan Seseorang Dibenarkan?}

Pada sisi lain, pemunculan pragmatisme dan cara hidup manusia abad XXI yang cenderung pragmatis yang menekankan manfaat perbuatan bagi kehidupan manusia sebagai suatu ancaman bagi kebenaran Kristen, yaitu "Mungkinkah seorang dibenarkan karena perbuatan?" Pertanyaan ini penting di kalangan orang Kristen karena pengajaran teologi yang menjadi titik tolak perjuangan para reformator adalah dibenarkan oleh iman telah mendarah daging dalam dunia teologi Kristen sehingga muncul pertanyaan, "bagaimana dengan kebenaran perbuatan?"

Masalah ini penting untuk dikaji, mengingat penyebab munculnya filsafat pragmatisme adalah karena tidak terpecahkannya masalahmasalah metafisik yang telah membingungkan manusia tentang kebenaran dan sulitnya pembuktian masalah-masalah metafisik dengan akal dan indrawi. Seolah-olah pemunculan filfasat pragmatisme dianggap sebagai jalan keluar urrtuk mengatasi masalah tersebut dengan menentukan faedahnya suatu kebenaran bagi manusia agar manusia

\footnotetext{
${ }^{1}$ Sonny E. Zaluchu, "Perkembangan Teologi Kristen di Dekade Pertama Abad XXI" dalam T. Sutarman, Bunga Rampai Jenis-Jenis Teologi pada Periode 1990-2009: Kumpulan Makalah dan Unduhan dari Internet (Semarang:STT Baptis, Oktober 2009), 129.

${ }^{2}$ Ibid.
} 
terlepas dari masalah yang dialaminya. ${ }^{3}$ Kebenaran pragmatisme adalah manfaat sebuah perbuatan lebih penting dari kebenaran iman.

\section{Pentingnya Memahami Filsafat Pragmatisme}

Pragmatisme" adalah ajaran, paham, atau pemikiran yang didasarkan pada tindakan atau perbuatan. ${ }^{4}$ Adapun kriteria kebenarannya adalah "faedah" atau "manfaat" dari tindakan atau perbuatan. Suatu teori atau hipotesis menurut pragmatisme adalah benar jika membawa hasil yang dapat diaplikasikan. ${ }^{5}$ Pada prinsipnya, pragmatisme adalah aliran filsafat yang menekankan bahwa benar tidaknya suatu ucapan, dalil, atau teori semata-mata bergantung kepada berfaedah atau tidaknya ucapan, dalil, atau teori tersebut bagi manusia untuk bertindak dalam kehidupannya. ${ }^{6}$ Pragmatisme menekankan kebenaran sebuah perbuatan bergantung pada manfaatnya bagi manusia lebih penting dari pembenaran yang dilakukan Allah terhadap orang percaya.

\section{Posisi Filsafat Pragmatisme dalam Teologi Kontemporer}

Filsafat pragamatisme tidak menjadi bagian dalam perkembangan teologi kontemporer karena mungkin pragmatisme menekankan manfaat perbuatan dari pada masalah metafisis. Namun jika disimak pemunculan filsafat pragmatisme dan dikaitkan dengan salah satu ciri teologi kontemporer yang menekankan pengaruh filsafat dan peran akal, ${ }^{7}$ maka sebagai aliran filsafat, pragmatisme juga memiliki pengaruh terhadap awal pemunculan teologi kontemporer.

\footnotetext{
${ }^{3}$ Leila Amra, "Dekonstruksi Pragmatisme," diakses pada tanggal 10 Mei 2010; tersedia http://www.gaulislam.com/dekonstruksi-pragmatisme dimuat pada tanggal 8 September 2007.

${ }^{4}$ Pragmatisme berasal dari kata dalam bahasa Yunani, yaitu "pragma" yang berarti perbuatan atau tindakan, dan "isme" yang berarti aliran, ajaran atau paham. ${ }^{5}$ Mohammad Najib Abdullah, "Pragmatisme: Sebuah Tinjauan Sejarah Intelektual Amerika," diakses pada tanggal 11 Mei 2010; tersedia di http://ibrary.usu.ac.id/download/ts/sejarah-mohammad.pdf e-USU Repository 2004.

${ }^{6}$ Leila Amra, "Dekonstruksi Pragmatisme"; diakses pada tanggal 10 Mei 2010; tersedia di http://www.gaulislam.com/dekonstruksi-pragmatisme dimuat tanggal 8 September 2007

${ }^{7}$ Eta Lintemann, Teologi Kontemporer: Ilmu atau Praduga? (Malang: Institut Injil Indonesia, 1991), 17-20; T. Sutarman, "Dasar Teologi Kontemporer (Filsafat yang Menggunakan Akal)" materi pembelajaran Colloquium Theologiqum (Semarang: STT Baptis, Mei 2010), n.p.
} 


\section{LATAR BELAKANG PEMUNCULAN FILSAFAT PRAGMATISME}

Pada Abad Pertengahan (abad ke V-XV), ajaran-ajaran Gereja menguasai Eropa dan gereja disibukkan dengan masalah-masalah metafisik yang abstrak seperti Tuhan, manusia, kosmos, dan etika. ${ }^{8}$ Namun dalam perkembangannya, sekitar abad XIV-XVIII dunia memasuki filsafat Modern yang isu utamanya adalah epistemologi dalam arti Teori Pengetahuan. ${ }^{9}$ Adapun masalah-masalah yang muncul pada masa ini adalah,

Pertama, bagaimana kemampuan akal dalam memperoleh pengetahuan tentang dunia eksternal. Kedua, sejauh mana kemampuan akal dapat menyerap struktur realitas. Ketiga, bagaimana kemampuan ide akal dalam menghadirkan dan menyingkap hakikat alam. Keempat, sampai di mana kemampuan akal dalam mencapai batas-batas kebenaran. ${ }^{10}$

Tanda dari pemunculan filsafat modern adalah masa Renaisans dan Pencerahan. Pada masa Renaisans (sekitar abad XIV-XVII), filsafat difokuskan pada masalah-masalah empiris yang didasarkan pada pengenalan indrawi. Pemunculan Renaisans sebagai upaya untuk memberikan kebebasan penuh kepada akal dan menjadikan fakta empirik sebagai sumber pengetahuan sebagai sikap untuk melepaskan diri dari kekangan dan belenggu gereja. Dengan perkataan lain, pemunculan Renaisans sebagai tindakan untuk melepaskan diri dari keterikatan terhadap agama dan beralih kepada kebebasan akal untuk berkreasi. ${ }^{11}$

Sekitar abad XVIII, peradaban dunia memasuki masa Pencerahan. Pada masa ini, pembahasan tidak difokuskan pada interpretasi baru terhadap dunia, manusia, dan Tuhan, tetapi beralih kepada masalah pemerintahan dan kenegaraan, agama, ekonomi, hukum, dan

\footnotetext{
${ }^{8}$ Edi Purwanto, "Merentang Nalar Pragmatism”; diakses pada tanggal llMei 2010; tersedia di http://jendelapemikiran.wordpress.com/2008/02/25/merentang-nalarpragamatisme dikutip tanggal llMei 2010.

9 Rodliyah Khuza'i, Dialog Epistemologi Mohammad Iqbal dan Charles S. Peirce (Bandung: Refika Aditama, 2007), 11.

${ }^{10}$ Milton K. Munitz, Contemporary Analytic Philosphy (New York: Macmillan Publishing Company Inc., 1981), 1. Dikutip oleh Rodliyah Khuza’i, 2007, 13.

${ }^{11}$ Edi Purwanto, "Merentang Nalar Pragmatism" ;diakses pada tanggal 11 Mei 2010; tersedia di http://jendelapemikiran.wordpress.com/2008/02/25/merentang-nalarpragamatisme.
} 
pendidikan. ${ }^{12}$ Pada masa ini, manusia memusatkan perhatian kepada kehidupan dunia dari pada akhirat dan lebih memercayai diri sendiri dan berusaha untuk membebaskan diri dari kekuasaan tradisi dan gereja. ${ }^{13}$ Klimaksnya, dunia filsafat menghasilkan dua aliran yang berbeda, yaitu Rasionalisme dan Empirisme. Rasionalisme menekankan sumber pengetahuan yang dapat dipercaya oleh rasio (akal), sedangkan Empirisme menekankan bahwa sumber pengetahuan manusia adalah pengalaman manusia yang didasarkan pada indera. ${ }^{14}$

Akhir abad XIX hingga abad XX, dunia filsafat memasuki masa Kontemporer. ${ }^{15}$ Filsafat kontemporer mengacu pada arti proses dan prosedur sebagai upaya untuk memperoleh pengetahuan yang dikenal dengan Metodologi. Ciri-cirinya adalah:

Pertama, peran bahasa dalam berkomunikasi dan berpikir, atau jaminan adanya makna dalam penggunaan bahasa; kedua, ujian logika penelitian atau metodologi, yaitu mengevaluasi berbagai teknik serta persyaratan dalam memperoleh keyakinan yang benar dan tuntutan klaim-klaim pengetahuan; ketiga, ujian filosofis terhadap sumber-sumber logika formal dalam bentuk modern. ${ }^{16}$

Ini menunjukkan bahwa pada masa ini, manusia berupaya untuk memahami kebenaran berdasarkan penggunaan bahasa, penelitian, dan pengujian razio, yang berbeda dengan masa sebelumnya yang menekankan pada akal dan pengalaman untuk membebaskan diri dari keterikatan terhadap doktrin-doktrin agama yang bersifat metafisik.

Menurut analisa Milton Munitz, aliran filsafat yang pertama muncul pada masa kontemporer adalah pragmatisme dengan tokohnya adalah Charles Sanders Peirce ${ }^{17}$ yang membentuk teori tertentu di antara banyak teori modern untuk menjelaskan pikiran manusia melalui ujian eksperimen dan pengamatan terhadap hasilnya. ${ }^{18}$ Peirce dengan pragmatismenya muncul untuk menanggapi masalah pengetahuan sebagai suatu upaya untuk membuktikan kebenaran secara empiris. Tindakan Peirce adalah “... usaha untuk menyatukan ilmu pengetahuan 118

${ }^{12}$ Asmoro Achmadi, Filsafat Umum (Jakarta: Rajawali Press, Edisi Revisi 2010),

${ }^{13}$ Rodliyah Khuza'i, Dialog Epistemologi Mohammad Iqbal dan Charles S. Peirce (Bandung: Refika Aditama, 2007), 11.

${ }^{14}$ Edi Purwanto, "Merentang Nalar Pragmatism," diakses pada tanggal 11 Mei 2010; tersedia di http://jendelapemikiran.wordpress.com/2008/02/25/merentang-nalarpragamatisme.

${ }^{15}$ Milton K. Munitz, 1981, l. Dikutip oleh Rodliyah Khuza'i, 2007, 13.

${ }^{16}$ Milton K. Munitz, 1981, 1. Ibid, 14.

${ }^{17}$ Milton K. Munitz, 1981, 8-9. Ibid.

${ }^{18}$ Ibid., 35. 
dengan filsafat agar dapat menjadi ilmiah dan berguna bagi kehidupan manusia ...," dan menjadi " ... suatu metode untuk memecahkan berbagai perdebatan filosofis metafisik yang tiada henti-hentinya, yang hampir mewarnai seluruh perkembangan dan perjalanan filsafat sejak zaman Yunani kuno." ${ }^{20}$ Sehingga dalam perkembangannya, pragmatisme memiliki pengaruh yang besar dalam dunia filsafat, kegamaan, psikologi, dan pendidikan sebagai aliran yang berupaya untuk mencari dan membuktikan kebenaran yang diyakini oleh manusia berdasarkan perbuatan yang bermanfaat baginya.

\section{TOKOH-TOKOH FILSAFAT PRAGMATISME DAN KONSEP PEMIKIRANNYA}

Tokoh-tokoh pragmatisme yang terkenal dan memiliki pengaruh besar dalam pemunculan dan perkembangan Filsafat Pragmatisme adalah:

\section{Charles Sanders Peirce (1 839-1 9 I 4)}

Charles Sanders Peirce adalah seorang ahli logika, filsafat, matematika, dan kimia. Ia dianggap filsuf besar dari Amerika. Lahir pada tanggal 10 September 1839 dari pasangan Sarah Hunt Mills dan Benjamin Peirce di Cambridge, Massachusetts Amerika Serikat. Perkembangan ilmu yang dimilikinya sangat dipengaruhi oleh ayahnya yang adalah seorang professor matematika di Universitas Harvard. Tahun 1863, Charles Peirce menerima gelar Bachelor of Science dalam bidang kimia dari Universitas Harvard. Peirce meninggal pada tanggap 19 April 1914 di Milford, Pennsylvania Amerika Serikat. ${ }^{21}$ Sebagai seorang ilmuwan, Peirce dikenal dengan teorinya tentang propabilitas, studi gravitasi, dan logika metodologi ilmiah. ${ }^{22}$ Beberapa konsep pemikiran C. S. Peirce tentang pragmatisme antara lain:

\footnotetext{
${ }^{19}$ Guy W. Stroh, American Philosophy (Princeton: Duven Nostrand Company, Inc.,
} 968), n.p., dikutip oleh Mohammad Najib Abbdulah; diakses pada tanggal 11 Mei 2010; tersedia di http://library.usu.ac.id/download/ts/sejarah-mohammad.pdf e-USU Repository 2004

${ }^{20}$ Ibid.

21 "Kajian Epistemologi Charles Sanders Pierce (1839-19140" oleh Gunawan dalam http://grelovejogja.worpress.com/2008/12/18/kajian-epistemologi-charlessanders-pierce-1839-1914/ dimuat pada tanggal 18 Desember 2008 dikutip tanggal 11 Mei 2010.

${ }^{22}$ Concise Encyclopedia Britannica, s.v. "Charles Sanders Peirce”; diakses pada tanggal 11 Mei 2010; tersedia di http://www.answer.com/topic/charles-pierce 


\section{Keabsahan Pemikiran Manusia}

Menurut Peirce, metodologi bukan untuk menjernihkan struktur logis dari teori-teori ilmiah melainkan menjernihkan logika prosedur untuk memperoleh teori-teori ilmiah. Bagi Peirce, proses penelitian tidak terlepas dari kehidupan konkret sehari-hari karena merupakan salah satu kegiatan hidup. Dalam kehidupan sehari-hari, manusia mengatur tindakan-tindakannya untuk mengantisipasi peristiwaperistiwa yang menghadangnya. Sebagian besar tindakan manusia adalah sebagai hasil konsensus yang dicapai secara intersubyektif. Suatu informasi dikatakan ilmiah jika hanya konsensus yang tetap dan tidak dipaksakan dengan memerhatikan kesasihannya. Demikian pula pengetehuan yang disebut pengetahuan adalah pengetahuan yang tidak dipaksakan dan bersifat intersubyektif. ${ }^{23}$ Peirce menegaskan,

Suatu konsensus ilmiah tidak harus definitif karena pernyataan pernyataan yang dihasilkan selalu dapat diperbaiki. Kendatipun demikian, konsensus itu harus bertujuan mencapai kesepakatan defenitif. Secara prinsip harus diyakini mungkinnya suatu jawaban final bagi setiap masalah yang muncul. Tanpa prinsip ini kita tak pernah dapat membedakan secara tegas pernyataanpernyataan yang benar dari yang salah. ${ }^{24}$

Peirce juga berpendapat bahwa masalah muncul dari pikiranpikiran manusia. Pada satu sisi, pikiran mengandung unsur yang berubah-ubah, tergantung pada batas-batas lingkungan dan kondisikondisi individu, pada sisi lain, pendapat-pendapat manusia secara universal cenderung mencapai titik definitif atau mencapai kebenaran. Namun dalam pencapaian kesimpulan akhir, pikiran-pikiran individu tidak memadai, karena mengandung kesalahan-kesalahan, untuk itu diperlukan konsensus untuk memperoleh jawaban-jawaban yang definitif. ${ }^{25}$ Dengan demikian, keabsahan pemikiran manusia bergantung pada konsensus yang disepakati untuk mengatur jalan pikiran dan tindakan sebagai cara untuk mengatasi hal-hal yang menghalanginya.

\section{Kebenaran}

Sebagai seorang ilmuan, Peirce telah memberikan sumbangsih besar dalam bidang logika kebenaran. Menurut Peirce, jenis-jenis kebenaran adalah,

\footnotetext{
${ }^{23}$ Gunawan, "Kajian Epistemologi Charles Sanders Peirce (1839-19140)" dikutip tanggal 11 Mei 2010; tersedia di http://grelovejogja.worpress.com/2008/12/18/kajianepistemologi-charles-sanders-pierce-1839-1914/ dimuat pada tanggal 18 Desember 2008 ${ }^{24}$ Ibid

${ }^{25}$ Ibid.
} 
Pertama, apa yang disebutnya sebagai kebenaran transsendental (transcendental truth) yang dimiliki oleh dan berada secara inheren dalam setiap sesuatu "sebagai sesuatu itu sendiri" (thing as a thing). Kebenaran-kebenaran itu merupakan karakter real (real character) yang dimiliki oleh sesuatu obyek, baik diketahui maupun tidak. Kedua, kebenaran kompleks (complex truth) yang berupaya kebenaran-kebenaran proporsional. Jenis ini dapat dibagi lagi menjadi jenis-jenis yang lebih rinci, seperti kebenaran etik (ethical truth) atau veracity yang berdasar pada kesesuaian sebuah proposisi dengan keyakinan seorang pembicara (atu penulis), serta kebenaran logis (logical truth) yang kriterianya adalah kesesuaian sebuah proposisi terhadap realitas. ${ }^{26}$

Dengan demikian, kebenaran yang dimaksudkan Peirce adalah apa yang nyata dari obyek, baik yang diketahui maupun tidak, bergantung kepada obyek itu sendiri, keyakinan orang yang menilai, dan kesesuaian proposisi dengan kenyataan.

\section{Etika}

Menurut Pierce, teori nilai berbeda dengan etika. Etika terfokus pada tujuan dan tidak hanya terfokus pada masalah benar dan salah. Untuk itu, masalah mendasar dari etika bukan pada 'benar', tetapi pada apa yang telah disiapkan seseorang dengan hati-hati untuk menerima sebagai ungkapan apa yang ia ingin lakukan, apa tujuan dirinya, apa yang ia akan akan lakukan setelah itu, dan untuk apa ia mengarahkan kekuatannya. $^{27}$

\section{Keyakinan}

Menurut Peirce, belief dan ide-ide terletak pada inti keberadaan manusia, karena hanya manusia yang memiliki keyakinan dan menggunakan ide-idenya. ${ }^{28}$ Peirce menegaskan,

Belief adalah pernyataan yang tegas mengenai proposisi yang dinilai benar. Ia merupakan persiapan yang secara sadar dari seseorang untuk berbuat dengan cara yang pasti. Ia menjelaskan kebiasaan (habit) akal, lawan dari keraguan. Keyakinan (belief) adalah

\footnotetext{
${ }^{26}$ Frederick Copleston S. J., Contemporary Philosophy (London: Cardinal Books,
} 1963), 305-306. Dikutip oleh Rodliyah Khuza'i, 2007, 35-36.

${ }^{27}$ Arthur W. Burk (Editor), The Collected Papers of Charles Sanders Peirce, Vol 3 (Cambridge, MA: Harvard University Press, 1958), 198. Dikutip oleh Rodliyah Khuza'i, 2007, 116

${ }^{28}$ Rodliyah Khuza'i, 2007, 121. 
keyakinan dalam proposisi yang memiliki dua komponen, yaitu subyek dan predikat. Setiap proposisi yang telah memiliki predikat yang menjelaskan apa yang diyakini dan memiliki subyek yang menjelaskan apa itu keyakinan. ${ }^{29}$

Ini menunjukkan bahwa komitmen seseorang terhadap keyakinan yang dimilikinya dalam mengukuhkan dan mempertaruhkan kebenaran adalah keperluan tertinggi untuk menyatakan proposisi, yang mana diri sendirilah bertanggung jawab terhadap kebenaran. ${ }^{30}$ Komponen keyakinan bukanlah suatu kesadaran temporal, tetapi kebiasaan sebagai keinginan seseorang untuk berbuat dalam cara yang khusus, yang berlangsung secara terus-menerus atau sepanjang waktu. ${ }^{31}$ Dengan demikian, menurut Pierce, keyakinan merupakan unsur penting dari diri seseorang untuk melakukan yang benar.

\section{Willian James (1842-1910)}

William James adalah seorang psikolog, filsuf, dan ahli etika yang berlatar belakang pendidikan dokter medik. Ia adalah tokoh pragmatisme yang lebih terkenan dari C. S. Peirce dan tokoh yang mempromosikan ajaran pragmatisme secara radikal. ${ }^{32}$ Ia lahir di Astor House, New York tanggal 11 January 1842, anak dari Henry James, Sr., seorang yang kaya dan terkenal eksentrik pada masa itu. William James memulai pendidikan dokternya di Harvard Medical School tahun 1864 dan selama berada di Harvard, ia tertarik untuk belajar teologi. Namun karena menderita sakit ia harus pindah ke Jerman untuk sementara waktu dalam upaya penyembuhan hingga 1868 . Ia memperoleh gelar dokter medik pada tahun 1869 , tetapi ia tidak pernah melaksanakan praktek dengan profesinya sebagai dokter. Selama ia berada di Jerman dalam dengan penyakit yang dideritanya, ia menemukan bahwa minat dan keinginan yang sejati tidak terletak pada obat, tetapi pada filsafat dan psikologi. ${ }^{33}$

Pada tahun 1902, James mengambil kesimpulan, "Aku awalnya belajar kedokteran untuk menjadi ahli fisiologi, tapi aku hanyut ke dalam psikologi dan filsafat ... Aku tidak pernah memiliki pengajaran filosofi, kuliah psikologi pertama yang pernah saya dengar menjadi yang

\footnotetext{
Ibid., 121.

${ }^{30}$ Ibid.

${ }^{31}$ Ibid.

32 Mohammad Najib Abdullah, "Pragmatisme: Sebuah Tinjauan Sejarah Intelektual Amerika"; diakses pada tanggal 11 Mei 2010; tersedia di http:/library.usu.ac.id/download/ts/sejarah-mohammad.pdf e-USU Repository 20040.

33 "William James"; diakses pada tanggal 16 Mei 2010, tersedia di http://en.wikipedia.org/wiki/William_James
}

${ }^{29}$ Justus Buchler, Charles Peirce's Empiricism (New York: Octagon Books, 1980), 28. 
pertama saya berikan."34 Ini menunjukkan bahwa pengalaman hidup yang dialaminya lebih berpengaruh dari pada pendidikan yang kedokteran yang pernah dijalaninya. Sebagai seorang yang mempromosikan filsafat pragmatis, William James memiliki beberapa konsep pemikiran yang terkenal seperti:

\section{Kebenaran}

Menurut William James, "Pengertian itu benar, jika pada praktek dapat dipergunakan. Putusan yang tidak dapat dipergunakan itu keliru ... Pengertian atau putusan itu benar, tidak saja jika terbuktian artinya dalam keadaan jasmani ini, akan tetapi jika bertindak (dapat dipergunakan dalam lingkungan ilmu, seni, dan agama)." ${ }^{35}$ James juga menekankan bahwa kebenaran adalah pemeriksaan terhadap lingkup pemikiran-pemikiran dan pernyataan-pernyataan sesuai dengan hal-hal yang sebenarnya, serta sejauh mana mereka bersatu atau melekat sebagai potongan teka-teki yang cocok satu sama lain, yang pada gilirannya, diverifikasi oleh hasil aplikasi pengamatan dari sebuah ide kepada praktek yang sebenarnnya. ${ }^{36}$ James juga menambahkan, kebenaran yang obyektif adalah kebenaran dalam pembentukan fungsi yang memberi kepuasan kepada manusia yang pada bagian sebelumnya yang tidak memainkan peran apa pun, tetapi yang sekarang ditemukan. ${ }^{37}$

James berpendapat bahwa alasan mengapa kita menyebut sesuatu benar adalah alasan mengapa hal itu benar, dan untuk menjadi benar berarti hanya menyatakan penyatuan fungsi. Sesuatu disebut benar, jika berfungsi dalam kehidupan manusia, bekerja dalam jangka waktu yang lama, dan menuntun manusia menjalani hidup di dunia yang tidak sepenuhnya ramah. ${ }^{38}$

Dalam bukunya The Meaning of Truth, James juga berpendapat bahwa kebenaran mengadung tiga aspek penting,

Pertama, kebenaran itu merupakan suatu postulat, yakni semua hal yang di satu sisi dapat ditentukan dan ditemukan berdasarkan pengalaman, sedang di sisi lain, siap diuji dengan perdebatan atau diskusi. Kedua, kebenaran merupakan suatu pernyataan fakta, artinya ada sangkut pautnya dengan pengalaman. Ketiga,

\footnotetext{
${ }^{34}$ Ibid.

${ }^{35}$ I. R. Poedjawijatna, Pembimbing ke Arah Alam Filsafat (Jakarta: Bina Aksara, 1983), 132.

36 "William James" diakses pada tanggal 16 Mei 2010;

tersediahttp://en.wikipedia.org/wiki/William_James dikutip tanggal 16 Mei 2010.

${ }^{37}$ Ibid.

${ }^{38}$ Ibid.
} 
kebenaran itu merupakan kesimpulan yang telah diperumum (digeneralisasikan) dari pernyataan fakta. ${ }^{39}$

Dengan demikian, kebenaran yang dimaksudkan James memikili makna fungsi, dapat dipraktekkan, dan memberi pengaruh kepada manusia dalam berbagai bidang kehidupan manusia, namun kebenaran yang dimaksud adalah relatif, tidak tetap dan dapat berubah. Untuk itu diperlukan pengujian melalui pembahasan perdebatan dan diskusi. Inilah proses yang untuk menghasilkan kebenaran.

\section{Keyakinan}

Menurut James, jika apa yang benar adalah apa yang telah dihasilkan atau dikerjakan, maka kita dapat secara ilmiah menemukan tuntutan agama untuk kebenaran dengan cara yang sama. Kebertahanan kualitas dari keyakinan-keyakinan agama telah dicatat sepanjang sejarah dan dalam semua budaya telah diakui bahwa keyakinan-keyakinan seperti itu telah berhasil. Dengan perkataan lain, keyakinan keagamaan telah sangat berguna dalam kehidupan manusia seperti keyakinan ilmiah. Dengan cara demikian, seseorang dapat mengasumsikan kepercayaannya kepada Allah dan membuktikan keberadaannya dengan keyakinan yang dimilikinya untuk membawanya kepada hidup. ${ }^{40}$

Pendapat James yang demikian menunjukkan bahwa keyakinan keagamaan sama dengan keyakinan ilmiah yang diperoleh melalui suatu proses ilmiah, bukan penyerahan hidup seseorang kepada yang dipercayainya. James berupaya membuktikan keyakinan keagamaan sesuai dengan konsep kebenaran pragmatisme.

\section{Kehendak Bebas}

James menegaskan bahwa kehendak dirinya adalah bebas. Tindakan kebebasannya yang pertama adalah memilih untuk memercayai bahwa kehendaknya adalah bebas. James juga menegaskan bahwa determenisme kuno adalah determenisme yang keras. Determenisme tersebut menunjukkan kata-kata yang kasar seperti kematian, pebudakan kehendak, dan yang sejenisnya, tetapi sekarang yang ditekankan adalah determenisme lunak, yaitu membenci kata-kata kasar, menyangkal kematian, dan mengupayakan kebebasan, karena kebebasan adalah kebutuhan yang dipahami, dan perbudakan yang

\footnotetext{
${ }^{39}$ William James, The Meaning of Truth (Cambridge MA: Harvard University Press, 1909, Edisi 1975), n.p.; dikutip oleh Leila Amra dalam "Dekonstruksi Pragmatisme"; tersedia di http://www.gaulislam.com/dekonstruksi-pragmatisme

40 "William James"; diakses pada tanggal 16 Mei 2010; tersedia di http://en.wikipedia.org/wiki/William_James dikutip tanggal 16 Mei 2010.
} 
tertinggi adalah identik dengan kebebasan sejati. ${ }^{41}$ Ini menunjukkan bahwa James menekankan kehendak sebagai kebebasan manusia dan manusia akan mencapai titik kebebasan sejati jika manusia telah diperbudak oleh kebebasan itu sendiri, yang menurut James adalah halhal yang tidak menyusahkan, tetapi menyenangkan. ${ }^{42}$

\section{Agama}

Menurut James, pengalaman beragama harus menjadi topik utama dalam studi keagamaan bukan lembaga-lembaga agama sejak lembagalembaga agama sepenuhnya menjadi kelompok sosial yang jenius. Bahkan menurut James, variasi patologi dari pengalaman beragama harus dicari oleh para ahli psikologi sebab mempresentasikan hal yang paling dekat kepada mikroskop pikiran yang ada, yang mana hal ini menunjukkan kepada kita bentuk yang diperbesar secara drastis dari proses-proses yang normal. James juga berpendapat bahwa untuk berguna dalam menafsirkan dunia umum serta berbagi pengalaman dan kisah, kita harus membuat keyakinan melebihi hal-hal yang lain meskipun tidak dapat dibuktikan dengan pengalaman, tetapi hal tersebut membuat hidup menjadi lebih baik. ${ }^{43}$

\section{Wahyu}

James menyatakan bahwa ketika ia berada di bawah pengaruh nitrat oksida, ia mampu memahami konsep Hegel, dan berdasarkan pengamatannya, James menyimpulkan bahwa meskipun wahyu-wahyu mistik memiliki kebenaran, tetapi wahyu-wahyu tersebut adalah benar hanya untuk mistik. Bagi orang lain, wahyu-wahyu adalah ide-ide yang harus dipertimbangkan secara benar, tetapi tidak dapat mengklaim kebenaran tanpa pengalaman pribadi. ${ }^{44}$

\section{John Dewey (1859-1952)}

John Dewey lahir pada tanggal 20 Oktober 1859 di Burlington, ${ }^{45}$ negara bagian Vermont, Amerika Serikat. Ia dibesarkan di kota yang sama dari keluarga yang saleh dengan latar belakang ekonomi kelas menengah. ${ }^{46}$ Ibunya adalah orang Kristen yang berlatarbelakang gereja

\footnotetext{
${ }^{41}$ Ibid.

${ }^{42}$ Ibid.

${ }^{43}$ Ibid.

${ }^{44}$ Ibid.

${ }^{45}$ Harus Hadiwijono, Sari Sejarah Filsafat Barat II, Sari Sejarah Filsafat Barat II (Yogyakarta : Kanisius, 2004), hal. 133. Dikutip oleh dikutip oleh Fazlur Rahman, "Konsep Pendidikan John Dewey".

http://www.infogue.com/viewstory/2008/04/16/konsep_pendidikan_john_dewey

${ }^{46}$ Robert R Boehlke, Sejarah Perkembangan Pikiran dan Praktek Pendidikan Agama Kristen (Jakarta: BPK Gunung Mulia, 2005), 612.
} 
evangelikal sehingga memiliki pengawasan yang cukup ketat terhadap kehidupan rohaninya. ${ }^{47}$ Namun Dewey tidak senang dengan cara demikian dan menimbulkan kekecewaan baginya, karena baginya, perasaan agama tidak sehat jika dinilai dan dijelaskan secara seksama sejauh persaan itu ada, baik, dan sedang bertumbuh. ${ }^{48}$

Ia juga menyelesaikan pendidikan di Universitas Hopkins di kota Baltimore, negara bagian Maryland, dengan gelar $\mathrm{Ph}$. $\mathrm{D}$. di bidang filsafat pada tahun 1884. ${ }^{49}$ Di Unviersitas Cichago, Dewey menjabat sebagai Dekan Fakultas Filsafat pada tahun 1894. Pada saat itu, Departemen Ilmu Jiwa dan Departemen Pedagogi adalah bagian dari Fakultas Filsafat. Di sinilah Dewey mengembangkan konsep pedagogi yang dimilikinya melalui sebuah laboratorium yang setaraf dengan SD, SMP, SMA, dan sekolah kejuruan. Hasilnya sangat baik serta dipuji karena menjadi wadah pendidikan yang paling kreatif dalam dunia pendidikan di Amerika, bahkan di dunia pada saat itu, walaupun Dewey sendiri bukanlah seorang yang berlatar belakang kuliah dalam bidang pendidikan..$^{50}$ Dewey meninggal pada tanggal 1 Juli 1952 di New York dengan meninggalkan kurang lebih 700 artikel dan 42 buah buku dalam dalam berbagai bidang (filsafat, pendidikan, seni, sains, politik, dan pembaharuan sosial). ${ }^{51}$

Beberapa konsep pemikiran penting dari John Dewey yang memperngaruhi dunia filsafat dan pendidikan adalah:

\section{Filfasat}

Menyikapi permasalahan hidup dan kerumitan dalam memecahkan masalah yang dihadapinya secara pribadi serta masalah yang terjadi dalam masyarakat, Dewey tertarik pada filsafat pragmatisme seperti yang telah diajarkan oleh Charles Sanders Pierce (1839-1914) dan yang dipopulerkan oleh William James (1842-1910). Konsep prangmatisme menekankan bahwa, “... makna segala sesuatu tergantung dari hubungannya dengan apa yang dapat dilakukan," 52 dengan mengacu pada instrumentalis (hidup tidak memiliki tujuan akhir, tetapi tujuan antara dan sementara) dan eksperimentalis (perlunya metode

${ }^{47}$ Ibid, 613.

${ }^{48}$ Ibid, 612-613.

${ }^{49}$ Ibid, 613.

50 George Dykhuizen, The Life and Mind of John Dewey (Carbondale and Edwardsville, Illinois: Southern Illinois University, 1973), 7. Dikutip oleh Boehlke, 2005,614 .

5l Tauhid Bashori, "Pragmatisme Pendidikan (Telaah atas Pemikiran John Dewey)"; tersedia di http://www.geocities.com/HotSprings/6774/j-13.html. Dapat juga dilihat dalam Boehlke, 2005, 615.

${ }^{52}$ Uyoh Sadulloh, Pengantar Filsafat Pendidikan (Bandung: Alfa Beta, 2007), 118. 
eksperimen dan pengalaman dalam menentukan kebenaran). ${ }^{53}$ Untuk itu, setiap individu bertanggung jawab untuk terlibat dalam tugas yang berkesinambungan dalam membangun kembali dunianya. ${ }^{54}$ Pemahaman tersebut tergambar jelas dalam konsep yang dimiliki oleh Dewey, "Filsafat harus berpijak pada pengalaman (experience) dan menyelidiki serta mengolah pengalaman itu secara kritis-aktif ... Pemikiran kita berpangkal dari pengalaman-pengalaman dan bergerak kembali menuju ke pengalaman-pengalaman.. ${ }^{55}$

Dengan demikian, pengalaman dan metode menjadi penekanan Dewey sebagai dua unsur yang berperan penting dalam pembentukan manusia untuk menemukan kebenaran dan mengalami pertumbuhan. Pengalaman menjadi unsur tertinggi dalam kehidupan manusia untuk menentukan kebenaran dan metode digunakan untuk mencapai kebenaran yang terdapat dalam pengalaman. Pengalaman itu sendiri adalah hal yang tidak mutlak dan dapat berubah, maka kebenaran pun tidak mutlak dan dapat berubah. Inilah yang menyebabkan hidup bukanlah tujuan akhir, tetapi tujuan sementara, karena pengalaman yang dialami seseorang dalam hidupnya adalah tidak tetap, tidak mutlak, dan dapat berubah.

\section{Agama}

Menurut Dewey, agama adalah pengalaman emosi yang dialami seseorang dan berhubungan dengan rasa nyaman serta bebas dari kekawatiran yang tidak mungkin terucapkan dalam kata-kata secara lisan. ${ }^{56}$ Pengalaman spiritualitas dan kesusilaan seseorang didapat bukan dari pembentukan secara keagamaan, tetapi sebagai hasil perkembangan seluruh bakatnya, dan jati dirinya hanya dapat direalisasikan dalam masyarakat yang demokratis sehingga tidak diperlukan pelayanan gereja. ${ }^{57}$ Bagi Dewey, kerajaan Allah adalah kenyataan adikodrati yang berfaedah sebagai simbol tentang hubungan yang tertinggi yang pengembangannya dilaksanakan melalui pendidikan. Untuk itu, guru adalah orang yang memiliki peran paling penting, karena ia dianggap

${ }^{53}$ Ibid, 119. Juga dapat dilihat dalam Boehlke, 2005, 620.

${ }^{54}$ Boehlke, 2005, 620.

${ }^{55}$ Y. B. Suparlan, Aliran-Aliran Baru dalam Pendidikan (Yogyakarta: Andi Offset, 1984), 82-84. Dikutip oleh Fazlur Rahman dalam "Profesional Seorang Guru: Usaha Rekonstruksi terhadap Pengetahuan" ; tersedia di

http://www.infogue.com/viewstory/2008/04/16/konsep_pendidikan_john_dewey/

${ }^{56}$ Boehlke, 2005, 616.

${ }^{57}$ Ibid. 
sebagai nabi yang paling dipercaya untuk mendatangkan kerajaan Allah yang sebenarnya. ${ }^{58}$

Dewey berpendapat bahwa penyataan bukanlah berasal dari Tuhan, tetapi penemuan yang dilakukan manusia melalui hubungan sosial dalam masyarakat yang demokratis. Dalam masyarakat yang demokratis, masyarakat tidak terikat pada dogma yang berasal dari masa lampau, karena masyarakat berhak untuk mencari sarana dalam memecahkan masalah yang muncul pada saat ini. Kebebasan yang dimiliki manusia memacu perkembangan sains modern yang keberadaannya merupakan kesatuan yang lebih tinggi dari peran gereja di masa lampau. ${ }^{59}$ Kebenaran supernatural tidak dapat diakui karena itu adalah masalah adikodrati yang kebenarannya tidak dapat dibuktikan secara obyektif. ${ }^{60}$ Dewey juga berpendapat bahwa kesalahan yang dilakukan oleh manusia bukanlah dosa yang harus diampuni, karena kesalahannya adalah ketidaksesuian pelajaran dalam metode dengan akal. Sebenarnya yang diperlukan manusia adalah perubahan yang diterapkan kembali dan diperbaiki ulang agar ia menjadi benar. ${ }^{61}$

Dengan berpandangan demikian, bagi Dewey, tidak ada kebenaran dan nilai keagamaan serta kaidah moral dan etika yang tetap dan mutlak. Semuanya relatif dan selalu berubah seperti perubahan-perubahan yang terjadi dalam kebudayaan, masyarakat, dan lingkungan. Pengujian kualitas nilai dan kebenaran dilaksanakan dengan cara yang sama seperti yang digunakan untuk menguji kebenaran pengetahuan dengan metode empiris berdasarkan berbagai pengalaman manusia dalam kehidupan sehari-hari. Nilai bukanlah hal yang bersifat supernatural, universal, dan agamawi. Nilai adalah suatu yang disetujui melalui diskusi terbuka berdasarkan pada bukti-bukti empris dan obyektif, bukan dipaksakan dengan suatu kekuatan untuk diterima. ${ }^{62}$

Nilai dan kebenaran keagamaan bukanlah suatu yang diwahyukan, tetapi muncul dari keinginan, dorongan, perasaan, dan kebiasaan manusia sesuai dengan wataknya sebagai perpaduan antara faktor biologis dan sosial yang ada dalam diri dan kepribadiannya. ${ }^{63}$ Dengan demikian, nilai dan kebenaran bukanlah suatu yang dinyatakan dan tetap berlaku selama-lamanya, tetapi suatu proses yang dilakukan

${ }^{58}$ John Dewey, "My Pedagogic Creed" dalam Robert Ulich, Three Thousand Years of Educational Wisdom (Cambridge, MA: Harvard University, 1954), 638. Dikutip oleh Boehlke, 2005, 617.

${ }^{59}$ Boehlke, 2005, 617.

${ }^{60}$ Ibid, 618.

${ }^{61}$ John Dewey, Reconstruction in Philosophy (Boston: Beacon, 1920), 175 dan 177.

Dikutip oleh Boehlke, 2005, 620-621.

${ }^{62}$ Uyoh Sadulloh, Pengantar Filsafat Pendidikan (Bandung: Alfa Beta, 2007), 123.

${ }^{63}$ Ibid, 124. 
manusia untuk menghasilkannya, dan karena itu, agama haruslah bersifat demokrasi dan terbuka terhadap kemungkinan- kemungkinan untuk memperoleh nilai dan kebenaran yang baru. ${ }^{84}$

\section{Pendidikan}

Menurut Dewey, pendidikan adalah upaya menolong manusia agar dapat berefleksi terhadap masalah yang timbul dalam masyarakat dan upaya memperlengkapi mereka agar menghasilkan perubahan yang nyata dalam kehidupan mereka. Jika dalam proses pendidikan tidak ada pengaruh yang positif terhadap alam dan masyarakat, maka janganlah disebut pendidikan, karena pendidikan harus memberikan pengaruh perubahan dan pertumbuhan. ${ }^{65}$

Sifat sosial adalah yang penting dari pendidikan itu. Untuk itu, peran masyarakat yang demokratis adalah bagian integral dalam mengembangkan sumber daya manusia, karena setiap warga adalah pribadi yang berharga, bukanlah sebagai alat untuk melayani maksud negara atau sarana untuk mencapai tujuan dari pihak yang berkuasa. Dengan cara ini, pendidikan berorietasi pada mempersiapkan lingkungan belajar yang memacu pengalaman untuk bertumbuh. ${ }^{66}$

Rumusan Dewey tentang pendidikan adalah “... pembentukan kembali atau pengorganisasian ulang pengalaman yang menambah maknanya dan yang menambah kemampuan si pelajar dalam memberi arah terhadap pengalaman yang selajutnya." ${ }^{67}$ Dan untuk mencapai maksud tersebut, guru memiliki peranan penting untuk membimbing pelajar memperluas pengetahuan dan kemampuan berpikirnya dalam menjelajah hubungan baru yang dibangunnya di atas pengetahuan yang dimiliki sebelumnya. ${ }^{68}$ Dalam hal ini, Dewey menekankan bahwa setiap orang belajar dari pengalamaannya yang berasal dari aktivitas yang asli dari lingkungannya. ${ }^{69}$

Tujuan pendidikan, menurut Dewey, bukanlah berada di luar kehidupan, tetapi berada dalam kehidupan itu sendiri. Untuk itu, pembentukan tujuan pendidikan harus didasarkan pada lingkungan masyarakat di mana anak didik hidup dan tempat di mana pendidikan berlangsung. Tujuan yang ditetapkan haruslah khusus, tidak berlaku secara universal, dan temporer, karena tidak ada kebenaran dan nilai yang mutlak dan berlaku secara universal. Tujuan pendidikan adalah

\footnotetext{
${ }^{64}$ Boehlke, 2005, 618.

${ }^{65}$ Ibid., 621 .

${ }^{66}$ Ibid., 621-622.

${ }^{67}$ John Dewey, Democracy and Education (New York: Macmillan, 1964), 328. Dikutip oleh Boehlke, 2005, 622

${ }^{68}$ Ibid.

${ }^{69}$ Uyoh Sadulloh, Pengantar Filsafat Pendidikan (Bandung: Alfa Beta, 2007), 125.
} 
sebagai instrumen untuk bertindak, yang hasilnya akan menjadi instrument untuk pencapaian tujuan berikutnya dan dijadikan sebagai alat untuk bertumbuh. ${ }^{70}$

John Dewey memiliki dua tujuan penting yang harus diperhatikan dalam menjalankan pendidikan. Pertama, upaya untuk membedakan hasil-hasil (results) dan tahap akhir (end). Tahap akhir adalah hasil dari langkah-langkah yang berkesinambungan dan teratur yang diambil secara cerdas, bukan dari kegiatan yang dilaksanakan pada tahap awal. Kedua, terdapat tiga langkah untuk mencapai tujuan dalam pendidikan, yaitu: 1) mengidentifikasi faktor-faktor penghalang bagi para pelajar yang menyebabkan tidak tercapainya tujuan, dan bersamaan dengan itu, harus diperhatikan sarana yang tersedia untuk mencapai tujuan yang dimaksud; 2) merumuskan urutan pemanfaatan sarana yang ada; 3) mempertimbangkan kegunaan dari semua sarana yang tersedia untuk mencapai tujuan yang dimaksud. ${ }^{71}$

Menurut Dewey, kurikulum (pokok yang dipelajari) berupa metodologi (proses yang terlibat di dalamnya) dan metodologi mencakup kurikulum, yang mana keduanya menyatu. ${ }^{72}$ Kurikulum berisi pengalaman-pengalaman yang teruji yang dapat diubah dan dapat dibentuk berdasarkan minat dan kebutuhan siswa, dan metodenya adalah learning by doing yang terfokus pada keaktifan siswa.

\section{Richard Rorty (1931-2007)}

Richard Rorty adalah penerus tradisi pragmatisme Amerika. Ia dianggap sebagai pendiri Neo-Pragmatisme, yang mana pandangannya sesuai dengan isu postmodernisme, karena Rorty mengajak untuk selalu membuka diri dan memperbaharui diri melalui dialog yang dilakukan secara terus-menerus dari pada mempertahankan status quo dan merasa puas terhadap hasil-hasil yang telah dicapai. ${ }^{73}$ Beberapa konsep pemikiran Richard Rorty yang terkenal adalah:

\section{Kebenaran}

Menurut Rorty, kebenaran tidak terpisah dari manusia seperti matahari yang menyinari manusia agar manusia tidak tertipu oleh baying-bayang duniawi. Kebenaran bukanlah hasil penemuan refleksi tentang pengetahuan yang tetap, tetapi diciptakan melalui penggunaan dan pemahaman bahasa bersama. Bagi Rorty, pembuktian kebenaran

\footnotetext{
${ }^{70}$ Sadulloh, 2007, 128-129.

${ }^{71}$ Boehlke, 2005, 623.

${ }^{72}$ Ibid., 626.

${ }^{73}$ Achmad Dardiri “Kritik terhadap Epistemologi dalam Pragmatisme Richard Rorty" ; tersedia di http://www.digilib.ui.ac.id/opac/themes/libri2/detail.jsp?id=80140.
} 
tentang apa yang benar mengenai gambaran dunia adalah berasal dari percakapan dan tindakan konkret antar manusia. ${ }^{74}$

\section{Bahasa}

Rorty berpendapat bahwa bahasa bukanlah cermin atas kenyataan melainkan alat untuk memungkinkan kosakata-kosakata lama dapat diperbaiki. Bahasa sebagai kebiasaan manusia dalam upaya untuk mengatasi masalah dengan lingkungan di mana ia berada yang mana kosakata yang baru muncul sebagai solusi. Kosakata pada akhirnya berubah menjadi keyakinan yang dapat dideskripsikan kembali setelah kegunaannya tidak ada lagi. Karena makna bahasa ditentukan oleh aturan bahasa dari bentuk-bentuk kehidupan yang khusus, maka tuntutan-tuntunan pemberlakukan secara universal menjadi hal yang tidak masuk akal. ${ }^{75}$

\section{Dasar Hidup}

Rorty beranggapan bahwa sebagai pribadi, manusia akan sadar tentang ketidakkekalan dan keterbatasan dirinya. Karena itu, manusia tidak akan mengupayakan kebenaran yang melampaui sejarah. Manusia akan sadar bahwa kosakata dalam bahasa yang dimilikinya telah terbentuk sebelumnya di tempat ia tinggal. Untuk itu, kesadaran bagi manusia tidak lain dari jaringan keyakinan, keinginan, dan emosi dengan tempat di mana ia berada agar ia dapat mempertahankan keanggotaan dalam komunitasnya. Bagi Rorty, kesadaran manusia tidak akan pernah murni dan netral, tetapi berakar dalam praktik kebahasaan. Dengan ini, manusia akan menguji dirinya, dengan cara, terbuka pada orang lain dan tidak mengisolasikan diri. ${ }^{76}$

\section{Keyakinan}

Keyakinan tidak perlu didasarkan pada metafisis, tetapi didasarkan pada penggambaran ulang melalui percakapan terbuka. Kosakata komunitas akan memberlakukan keyakinan masing-masing. Dengan demikian, karya sastra lebih membangkitkan imajinasi, karena dengan membaca karya sastra orang lain, seseorang akan lebih peka terhadap penderitaan orang lain daripada ceramah agama yang membosankan dan usang. Contohnya, melalui puisi, seseorang dapat

\footnotetext{
${ }^{74}$ Richard Rorty, Phylosophy and the Miror of Nature (Oxford: Blackwell, 1980), 170. Dikutip oleh Achmad Dardiri; tersedia di

http://www.digilib.ui.ac.id/opac/themes/libri2/detail.jsp?id=80140.

${ }^{75}$ Ibid.

76 Richard Rorty, Objectivity, Relativism, and Truth (Cambridge: Cambridge University Press, 1991), 199. Dikutip oleh Achmad Dardiri dalam http://www.digilib.ui.ac.id/opac/themes/libri2/detail.jsp?id=80140.
} 
menciptakan dan menggambarkan ulang keyakinannya yang sama, dan dengan metafor, ia dapat menjaga pengalamannya yang rahasia tanpa diketahui oleh orang lain atau memaksa orang lain untuk tahu. ${ }^{77}$

\section{Manusia Ironis}

Manusia ironis adalah “... orang yang lebih mementingkan otonomi privat ketimbang otonomi publik. Ia tidak percaya bahwa ruang publik memberikan jawaban yang memuaskan dalam pencarian kesempurnaan hidup ... Ia curiga bahwa ruang publik telah dan akan memperkosa harga diri dan kesenangan pribadi." 78 Menanggapi hal ini, Rorty menilai bahwa manusia ironis adalah manusia yang tidak solider dan anti-sosial. Mereka hidup tidak sesuai dengan budaya liberal dan tidak memerhatikan serta mempertahakan tanggung jawab sosial. Mereka segan terhadap nilai-nilai keadilan dan kesejahteraan sosial untuk dimasukkan dalam tatanan sosial. Bagi Rorty, manusia ironis dapat sekaligus dapat menjadi manusia liberal. Ia dapat meragukan keyakinan publik tanpa melakukan aniaya untuk meyakinkan bahwa ia memiliki keyakinan dan prinsip hidup yang lebih baik. Ia dapat membentuk ulang imajinasinya dan sekaligus memiliki tanggung jawab sosial, karena otonomi privat tidak selalu bertentangan dengan otonomi publik, sehingga walaupun ia merasa sebagai yang otentik, ia tidak harus merusak komitmennya terhadap komunitas di mana ia berada. ${ }^{79}$

\section{Moral}

Dalam konsepnya tentang moral, Rorty menolak konsep etika tradisional yang menekankan bahwa manusia harus memiliki acuan obyektif-universal sebagai kriteria untuk menentukan tindakan manusia yang bermoral. Menurut Rorty, 'Moralis adalah praktik 'kekitaan' yang ada secara kebetulan.' Karena itu lebih baik seseorang dianggap bagian dari masyarakat daripada pengakuan sebagai sesama manusia yang bermartabat, karena untuk berbuat baik, orang tidak perlu jaminan metafisis seperti Tuhan atau atas dasar kehormatan, tetapi dengan mempertajam kepekaan terhadap penderitaan orang lain. ${ }^{80}$ Dengan demikian, keberadaan moralitas manusia tidak ditentukan lagi sebagai pengakuan kodrat manusia yang sejati, tetapi terkait dengan perasaan

\footnotetext{
77 Ibid.

${ }^{78}$ Ibid.

${ }^{79}$ Richard Rorty, Justice as Larger Community, 2001, 225. Dikutip oleh Achmad Dardiri dalam http://www.digilib.ui.ac.id/opac/themes/libri2/detail.jsp?id=80140 dikutip pada tanggal 14 Mei 2010.

${ }^{80}$ Richard Rorty, Truth and Progress (Cambridge: Cambridge University Press, 1988), 185. Dikutip oleh Achmad Dardiri dalam http://www.digilib.ui.ac.id/opac/themes/libri2/detail.jsp?id=80140.
} 
sentimental terhadap sesama, bukan lagi mengacu pada kewajiban yang tulus dari kehendak manusia, tetapi kemampuan untuk memercayai sesama. $^{81}$

\section{ANALISIS AJARAN FILSAFAT PRAGMATISME}

Dengan mencermati konsep pemikiran tokoh-tokoh Pragmatisme, maka dapat diberikan penilaian tentang sumbangsih dan kritik terhadap filsafat pragmatisme berdasarkan iman Kristen.

\section{Sumbangsih Filsafat Pragmatisme}

Pertama, secara umum, dapat dikatakan bahwa filsafat pragmatisme sebagai sarana untuk menolong manusia dalam kehidupan sehari-hari untuk mengembangkan ilmu pengetahuan dan mewujudkan dunia teknik (praktis). Praktek dan buah kehidupan seseorang adalah penting untuk menilai ia baik atau tidak dalam masyarakat di mana ia berada. Filsafat pragmatisme mengajarkan manusia untuk berbuat, bukan hanya berpikir, karena pikiran atau teori merupakan sarana yang hanya berguna untuk memungkinkan timbulnya pengalaman untuk ikut mengembangkan hidup manusia dalam praktek kehidupannya seharihari. $^{82}$ Filsafat pragmatisme menekankan bahwa yang benar hanyalah hal-hal yang mempengaruhi kehidupan manusia, berguna dalam praktek hidupnya, dan dapat memenuhi tuntutan hidup manusia. Sehingga yang menjadi penekanan penting adalah berbuat, bukan hanya berteori. ${ }^{83}$ Hidup adalah berbuat yang baik dan berguna untuk diri sendiri dan orang lain.

Kedua, Pragmatisme merupakan aliran filsafat yang mencoba untuk memberdayakan potensi yang dimiliki oleh manusia untuk dimanfaatkan secara maksimal di dalam hidupnya, secara khusus, dalam bidang ilmu pengetahuan. Teori-teori ilmiah adalah hasil logika berpikir manusia melalui metodologi penelitian ilmiah yang didiskusikan dan didialogkan bersama sehingga disetujui sebagai kebenaran ilmiah. ${ }^{84}$ Konsep ini sangat berpengaruh dalam dunia pendidikan, yang mana, teori-teori ilmiah yang dihasilkan melalui metodologi penelitian ilmiah

\footnotetext{
${ }^{81}$ Richard Rorty, 1998, 181. Dikutip oleh Achmad Dardiri dalam http://www.digilib.ui.ac.id/opac/themes/libri2/detail.jsp?id=80140.

${ }^{82}$ Najib Abdullah Mohammad, "Pragmatisme: Sebuah Tinjauan Sejarah Intelektual Amerika”; diakses pada tanggal 11 Mei 2010;tersedia di http://library.usu.ac.id/download/ts/sejarah-mohammad.pdf e-USU Repository 2004

${ }^{83}$ Ibid.

${ }^{84}$ Gunawan "Kajian Epistemologi Charles Sanders Peirce (1839-19140); diakses pada tanggal 11 Mei 2010; tersedia di http://erelovejogia.worpress.com/2008/ 12118/kajian-epistemologi-charles-sanders-pierce-1839-1914/ dimuat pada tanggal 18 Desember 2008.
} 
dapat diterima sebagai kebenaran ilmiah jika kebenaran ilmiah tersebut diuji melalui diskusi-diskusi ilmiah sehingga kebenaran ilmiah tersebut disepakati secara bersama untuk diberlakukan secara umum.

Ketiga, Pragmatisme melahirkan konsep pembelajaran activelearner oleh John Dewey dengan memerhatikan anak-anak adalah pembelajar aktif (active learner) agar dipacu untuk lebih aktif. Pendidikan seharusnya difokuskan kepada seluruh aspek kepribadian anak dan memperkuat kemampuannya untuk menyesuaikan diri dengan lingkungan di mana ia berada sehingga ia mampu memecahkan masalah yang dialaminya secara reflektif. Semua anak-anak, baik laki-laki maupun perempuan, dari semua lapisan sosial-ekonomi serta semua etnis, memiliki hak untuk mendapat pendidikan yang layak. Konsep Active-learner adalah konsep yang menunjukkan bahwa setiap anak didik memiliki kemampuan untuk betumbuh dengan memberdayakan seluruh potensi yang mereka mereka miliki melalui pendidikan yang mereka dijalani.

Keempat, Filsafat pragmatisme mengajarkan tentang kepedulian terhadap sesama dan lingkungan sosial di mana seseorang berbada untuk melakukan hal-hal yang bermanfaat atau berguna bagi orang lain dan lingkungannya (Rorty).

\section{Kritik terhadap Filsafat Pragmatisme}

Kritik terhadap manfaat kebenaran perbuatan pragmatisme didasarkan pada penilian kekristenan terhadap pokok-pokok pengajaran pragmatisme. Kritik yang dimaksud adalah:

\section{Pragmatisme Menolak Kebenaran Bersumber dari Allah}

Menurut filsafat pragmatisme: 1) Kebenaran berada pada sesuatu dan sesuatu itu sendiri yang menunjukkan keadaan yang sebenarnya baik yang diketahui dan yang tidak diketahui, atau kesesuaian yang disangka dengan yang nyata berdasarkan pengamatan logis (Peirce); ${ }^{85}$ Kebenaran adalah pengertian yang dapat digunakan dalam lingkungan agama, seni, dan ilmu(James). ${ }^{86}$ Kebenaran adalah pemikiran tentang keadaan yang sebenarnya yang memiliki manfaat dan kepuasan kepada manusia yang belum ditemukan sebelumnya (James), ${ }^{87}$ yang semuanya bergantung pada pengalaman dan fakta yang diuji melalui perdebatan

\footnotetext{
${ }^{85}$ Gunawan, “Kaiian Epistemologi Charles Sanders Peirce (1839-19140)”; diakses pada tanggal ll Mei 2010;tersedia di http://grelovejogja.wordpress.com/2008/12/18//kajian-epistemologi-charles-sanderspierce-1839-1914/

${ }^{86}$ I. R. Poedjawijatna, 1983, 132.

87 "William James"; diakses tanggal 16 Mei 2010;tersedia di http://en.wikipediaorg/wiki/William_James
} 
dan diskusi (James). ${ }^{88}$ Pengalaman adalah unsur tertinggi untuk menentukan kebenaran dan metode digunakan untuk mencapai kebenaran. Pengalaman itu sendiri tidak mutlak dan dapat berubah, maka kebenaran pun dapat berubah dan tidak mutlak (Dewey). ${ }^{89}$ Kebenaran yang supernatural tidak dapat diakui karena itu adalah masalah adikodrati yang kebenarannya tidak dapat dibuktikan secara obyektif (Dewey)..$^{90}$ 4) Kebenaran diciptakan melalui penggunaan dan pemahaman bahasa secara bersama atau melalui penggunaan dan pemahaman biasa yang terwujud dalam percakapan dan tindakan yang nyata (Rotty). ${ }^{91}$ Kebenaran bergantung kepada apa yang diyakini seseorang dan ia sendirilah yang bertanggung jawab terhadap kebenaran itu sesuai dengan apa yang diyakininya. Dengan perkataan lain, keyakinan diri adalah kebenaran diri yang bergantung kepada kebiasaan seseorang yang dilaksanakan secara terus-menerus seumur hidupnya (Peirce).

Konsep pragmatisme yang demikian menunjukan bahwa pragmatisme menolak Allah adalah kebenaran dan sumber kebenaran. Pragmatisme menolak hal-hal adikodrati yang berhubungan dengan kemahakuasaan Allah dalam melaksanakan segala rencana-Nya di luar jangkauan pemikiran, kemampuan, dan kekuatan manusia. Hal-hal yang dianggap kebenaran menurut pragmatisme, seperti pengalaman, fakta, dan bahasa dan perbuatan yang menjadi kebiasaan, dalam kekristenan, adalah sarana-sarana yang telah diciptakan dan dipakai Allah untuk menyatakan kebenaran-Nya agar Ia dapat dikenal dan disembah oleh ciptaan-Nya.

Dengan memercayai hanya kepada sarana yang diciptakan oleh Allah, maka pragmatisme juga tidak mengakui Yesus adalah Kebenaran yang menyelamatkan (Yoh. 14:6) dan tidak mengakui firman Allah (Alkitab) adalah kebenaran tertulis yang dinyatakan Allah kepada manusia, yang mana, jika manusia melakukannya maka ia akan hidup.

${ }^{88}$ William James, The Meaning of Truth (Cambridge MA: Harvard University Press, 1909, Edisi 1975), n.p.dikutip oleh Leila Amra dalam "Dekonstruksi Pragmatisme" dalam http://www.gaulislam.com/dekonstruksiptragmdbme dimuat tanggal 8 September 2007 dikutip tanggal 10 Mei 2010.

${ }^{89}$ Robert R. Boehlke, Sejarah Perkembangan Pikiran dan Praktek Pendidikan Agama

Kristen (Jakarta: BPK Gunung Mulia, 2005), 613.

${ }^{90}$ Ibid., 617.

${ }^{91}$ Achmad Dardiri, "Kritik terhadap Epistemologi dalam Pragmalisme Richard Rorty";tersedia di http://www.digilib.ui.ac.id/opac/themes/libri2/ detail jsp?id:80140.

${ }_{92}$ Justus Buchler, Charles Peiree's Empiricism (NewYork: Octagon Books, 1980), 28.

Dalam Rodliyah Khuza'i, 2007, 121. 


\section{Pragmatisme Menolak Alkitab sebagai Sumber Etika/Moral}

Menutur pragmatisme, etika dianggap sebagai tujuan hidup untuk mengantisipasi peristiwa-peristiwa yang dianggap sebagi penghalang hidup yang diatur melalui tindakan-tindakan. ${ }^{93}$ Tidak ada nilai keagamaan, kaidah moral dan etika yang tetap dan mutlak. Semuanya tidak tetap sesuai dengan perubahan-perubahan yang terjadi dalam masyarakat dan kebudayaannya (Dewey). ${ }^{94}$

Untuk memiliki etika dan moral yang baik, seseorang tidak memerlukan hal-hal metafisik, seperti Tuhan, tetapi dengan cara mempertajam kepekaan terhadap penderitaan orang lain. Seorang yang memiliki moral dan etika yang baik adalah orang yang memiliki keinginan untuk memercayai sesama dan kemampuan untuk menolong orang lain (Rorty). ${ }^{95}$

Konsep pragmatisme yang demikian menunjukkan bahwa pragmatisme tidak mengakui Alkitab adalah firman Allah yang menjadi sumber etika dan standar untuk beretika. Kekristenan mengakui bahwa firman Allah sifatnya tetap, mutlak, dan memiliki kuasa untuk mendatangkan kebaikan bagi orang yang melakukannya agar mereka tidak hidup dalam kedagingan, tetapi hidup oleh Roh, menghasilkan buah Roh (Gal. 5:16-23), dan memiliki kepedulian terhadap sesama. Dalam kehidupan sehari-hari, firman Allah "bermanfaat untuk mengajar, untuk menyatakan kesalahan, untuk memperbaiki kelakuan dan mendidik orang dalam kebenaran" (II Tim. 3:16). Inilah yang akan membuat orang percaya memiliki moral dan etika yang baik.

\section{Pragmatisme Menolak Pemenuhan Tujuan Hidup Berasal dari Allah}

Tujuan hidup menurut pragmatisme didasarkan pada etika karena etikalah yang membuat seseorang mencapai tujuan hidup. Apa yang telah disiapkan seseorang dengan hati-hati, apa tujuan dirinya, dan apa yang akan dilakukannya akan membawanya kepada tujuan hidup yang diinginkannya (Peirce). ${ }^{96}$ Tujuan hidup yang dimiliki manusia adalah didasarkan kepercayaannya kepada Allah yang sama dengan keyakinan

\footnotetext{
${ }^{93}$ Gunawan "Kajian Epistemologi Charles Sanders Peirce (1839-19140); diakses pada tanggal 11 Mei 2010; tersedia di http://erelovejogia.worpress.com/2008/ 12118/kajian-epistemologi-charles-sanders-pierce-1839-1914/ dimuat pada tanggal 18 Desember 2008

${ }^{94}$ Uyoh Sadulloh, 2007, 123.

${ }^{95}$ Richard Rofi, Truth and Progress (Cambridge: Cambridge University Press, 1988), 185. Dikutip oleh Achmad Dardiri dalam http:/lwww.digilib.ui.ac.id/ooaclthemeVlibri2/detailjsp?ił80140. Dan Richard Rorty, 1998, 181. Dikutip oleh Achmad Dardiri dalam http://www.digilib.ui.ac.id/opac/themes/libri2idetailjsp?id:80140.

${ }^{96}$ Arthur W. Burk (Editor), 1958, 198. Dikutip oleh Rodliyah Khuza'i, 2007, 116.
} 
terhadap kebenaran ilmiah (James). ${ }^{97} \quad$ Pada sisi lain, menurut pragmatisme, hidup bukahlan tujuan akhir, tetapi tujuan sementara dan ini didasarkan pada pengalaman. Karena pengalaman tidak tetap, tidak mutlak, dan dapat berubah, maka tujuan hidup pun demikian (Dewey). ${ }^{98}$

Nampaknya pragmatisme menunjukkan bahwa tujuan hidup manusia didasarkan kepercayaan kepada Allah, tetapi Allah yang dimaksud adalah Allah yang dapat dibuktikan dengan kebenaran ilmiah. Jika tidak, maka tidak ada kepercayaan kepada Allah untuk mencapai tujuan hidup. Sebenarnya, dalam kekristenan Allah adalah Pencipta yang memiliki hidup, sehingga segala upaya yang dilakukan manusia untuk mencapai tujuan hidup yang diinginkannya adalah berada dalam tuntunan dan pemeliharaan Allah. Manusia berupaya tetapi Allah-lah yang memberkati, membuka jalan, dan menuntun kepada tujuan hidup yang menjadi bagiannya.

\section{Pragmatisme Menolak Konsep Iman dalam Kekristenan}

Menurut pragmatisme, keyakinan menyangkut pertahanan diri, otoritas dan wibawa, kebebasan untuk memilih, dan desain logika melalui metode ilmiah (Peirce). ${ }^{99}$ Keyakinan agama dapat ditemukan atau dihasilkan melalui secara ilmiah dan berguna bagi kehidupan manusia seperti keyakinan ilmiah (James). ${ }^{100}$ Keyakinan agama harus melebihi hal-hal yang lain walaupun tidak dapat dibuktikan dengan pengalaman, namun membuat kehidupan manusia menjadi lebih baik (James). ${ }^{101}$ Pragmatisme juga menekankan bahwa keyakinan adalah kesadaran manusia dengan tempat di mana ia hidup agar ia dapat mempertahankan keanggotaan dalam komunitas di mana ia berada yang didasarkan pada kosakata dalam bahasa yang dimilikinya dan yang berlaku dalam komunitas tersebut. Untuk itu keyakinan tidak perlu didasarkan pada hal metafisis, tetapi berdasarkan penggambaran ulang melalui percakapan. Keagamaan yang baik adalah jika seseorang memiliki kepekaan terhadap orang lain melalui karya sastra yang membangkitkan imajinasinya. Jika manusia tidak memiliki kepekaan

\footnotetext{
97 "William James" diakses pada tanggal 16 Mei 2010 dalam http://en.wikioedia.org/wiki/William James

${ }_{98}$ Robert R. Boehlke, 2005, 613.

${ }^{99}$ Arthur W. Burk (Editor), Vol. 5, 1958,377-397. Dalam Rodliyah Khuza'I, 2007, 123.

100"William James" diakses pada tanggal 16 Mei 2010 dalam http://en.wikioedia.org/wiki/William James

${ }^{101}$ Ibid.
} 
yang demikian, ia disebut manusia yang ironis karena tidak solider dan anti sosial (Rorty). ${ }^{102}$

Pandangan pragmatisme tidak mengakui "iman adalah dasar dari segalasesuatu yang kita harapkan dan bukti dari segala sesuatu yang tidak kita lihat" (Ibr. 1l:1). Pragmatisme hanya menekankan perbuatan dan manfaatnya sehingga hal-hal yang tidak dapat dibuktikan dengan akal, bukanlah keyakinan. Berbeda dengan kekristenan, iman adalah kunci untuk memercayai hal-hal metafisis dan menjadi kunci untuk dibenarkan dan diselamatkan. Banyak hal dalam kekristenan tidak dapat dibuktikan dengan metode ilmiah, tetapi diyakini atau dipercayai, seperti Allah Bapa, Yesus adalah Allah dan Manusia yang sempurna, Roh, dan mujizat. Jika keyakinan didasarkan pada metode ilmiah, bahasa, dan kepekaan terhadap orang lain seperti yang dimaksud oleh pragmatisme, maka kekristenan ditolak oleh pragmatisme karena iman menjadi dasar pembentuk kekristenan seseorang.

\section{Pragmatisme Menolak Kedaulatan Allah dalam Kehidupan Manusia}

Kehendak manusia adalah kebebasan manusia untuk terlepas dari hal-hal yang menakutkan manusia. Kehendak bebas adalah keinginan manusia untuk menikmati hal-hal yang menyenangkan hidupnya tanpa terikat pada hal-hal yung menyusahkannya (James). ${ }^{903}$

Pandangan pragmatisme yang demikian menolak kedaulatan Allah atas berbagai pengalaman hidup yang dialami oleh manusia. Manusia memiliki berbagai pengalaman hidup yang diijinkan Allah untuk mengalaminya. Hal ini ditegaskan oleh Salomo,

Untuk segala sesuatu ada masanya, untuk apapun di bawah langit ada waktunya. Ada waktu untuk lahir, ada waktu untuk meninggal, ada waktu untuk menanam, ada waktu untuk mencabut yang ditanam; ada waktu untuk membunuh, ada waktu untuk menyembuhkan; ada waktu untuk merombak, ada waktu untuk membangun; ada waktu untuk menangis, ada waktu untuk tertawa; ada waktu untuk meratap; ada waktu untuk menari; ada waktu untuk membuang batu, ada waktu untuk mengumpulkan batu; ada waktu untuk memeluk, ada waktu untuk menahan diri dari memeluk; ada waktu untuk mencari, ada waktu untuk membiarkan rugi; ada waktu untuk menyimpan, ada waktu untuk

\footnotetext{
${ }^{102}$ Richard Rorty, Objectivity, Relalivisna and Truth (Cambridge: Cambridge University Press, 1991), 199. Dikutip oleh Achmad Dardiri dalam http://www.digilib.ui.ac.id/opac/themes/libri2/detail.jsp?id=80140.

103 "William James"; diakses pada tanggal 16 Mei 2010, tersedia di http://en.wikipedia.org/wiki/William.
} 
membuang; ada waktu untuk merobek, ada waktu untuk menjahit; ada waktu untuk berdiam diri, ada waktu untuk berbicara; ada waklu untuk mengasihi, ada waktu untuk membenci; ada waktu untuk perang, ada waktu untuk damai (Pengkhotbah 3:1-8).

Ini menunjukkan bahwa pengalaman hidup manusia adalah sesuatu yang variatif yang diijinkan Allah untuk dialami dan menjadi bagian hidup manusia. Walaupun demikian, Allah juga berdaulat untuk memberikan kekuatan, penghiburan, dan kemenangan, jika umat-Nya mengalami kesusahan, kesulitan, dan kedukaan. Salomo berkata, "Ia membuat segala sesuatu indah pada waktunya, bahkan Ia memberikan kekekalan dalam hati mereka. Tetapi manusia tidak dapat menyelami pekerjaan yang dilakukan Allah dari awal sampai akhir" (Pengkhotbah 3:11). Demikian pula yang dikatakan Paulus, "Segala perkara dapat kutanggung di datam Dia yang memberi kekuatan kepadaku" (Flp 4:13). Jadi tidak selamanya manusia hidup dengan hal yang menyenangkan dan menertawakan, tetapi ada saat juga manusia mengalami hal yang menyedihkan dan menyusahkan, namun di dalam semua itu, Allah berdaulat untuk memberikan pertolongan kepada umat-Nya.

\section{Pragmatisme Menolak Pengalaman Rohani}

Pengalaman spiritualitas dan kesusilaan dimiliki seseorang bukan karena pembentukan secara keagamaan, tetapi sebagai hasil dari pemberdayaan seluruh potensinya dan jati dirinya hanya dapat direalisasikan dalam masyarakat yang demokratis sehingga gereja tidak perlukan (Dewey). ${ }^{104}$

Konsep pragmatisme yang demikian menolak pengamalan pemilihan, penentuan, panggilan, pembenaran, den pemuliaan (Roma 8:29-30), penyemalatan (I Yoh-5:11-12), pengakuan dosa dan penyucian serta pengampunan dalam kekristenan (I Yoh. l:9). Dalam kekristenan, hal-hal tersebut adalah mutlak untuk dialami oleh orang-orang Kristen dan bersifat adikodrati. Pengalaman-pengalaman tersebutlah yang membuat keyakinan kekristenan seseorang semakin kokoh dan membuatnya semakin memercayai Allah di dalam hidupnya.

Pragmatisme Menolak Gereja sebagai Tubuh Kristus

Pragmatisme mengakui sifat sosial dalam pendidikan, ${ }^{105}$ tetapi ia lebih menekankan masyarakat yang demokratis ${ }^{106}$ dari pada komunitas Kristen yang adalah tubuh Kristus. Pelayanan gereja tidak diperlukan,

\footnotetext{
${ }^{104}$ Boehlke, 2005, 616.

${ }^{105}$ John Dewey, Democracy ond Education (New York: Macmillan, 1964),328. Dikutip oleh Boehlke, 2005, 622.

${ }^{106}$ Boehlke, 2005, 621 .
} 
tetapi masyarakat yang demokratis yang di dalamnya jati diri seseorang dapat direalisasikan (Dewey). ${ }^{107}$

Dalam konsep kekristenan, tidak ada satu pun kelompok masyarakat yang benar secara rohani di muka bumi ini yang diakui oleh Allah, selain gereja yang adalah tubuh Kristus, karena di dalamnya terdapat orang-orang pilihan Allah yang telah bertobat dari kehidupan lama dan menerima Yesus sebagai Juruselamat mereka. Di dalam tubuh Kristus, setiap anggota dilengkapi dengan pengajaran firman Allah dan memiliki kesempatan untuk memberdayakan potensinya sesuai dengan karunianya untuk melayani kebutuhan anggota yang lain (I Kor. 12:1231). Dengan perkataan lain, setiap onlng tidak hanya mengurus kepentingannya sendiri, tetapi bertanggung jawab terhadap seluruh anggota, dan sebaliknya, seluruh anggota bertanggung jawab terhadap setiap anggota dalam melakukan pekerjaan yang baik (Ef, 2:10; Ibr. 10:24).

Kesatuan, kehidupan, dan pelayanan di antara anggota dapat terjadi karena hanya satu Tuhan yang disembah, yaitu Yesus, dan hanya satu Roh yang diam di dalam setiap anggota (I Kor. 12:4-6). Roh-lah yang mengerjakan kesatuan di antara semua anggota dan memperlengkapi mereka dengan karunia-karunia agar mereka dapat bersatu dan saling melayani. Dengan bersatu dan saling melayani dan melengkapi satu dengan yang lain maka mereka semua akan mengalami pertumbuhan secara bersama.

Pragamatisme Menolak Dosa sebagai Pemberontakan terhadap Allah

Kesalahan yang dilakukan manusia bukanlah dosa yang harus diampuni karena kesalahan adalah ketidaksesuaian pelajaran dalam metode dengan akal. Jadi yang diperlukan manusia adalah perubahan yang diterapkan kembali dan yang diperbaiki ulang agar ia menjadi benar (Dewey). ${ }^{108}$

Dosa adalah pemberontakan terhadap hukum Allah yang merusak relasi manusia dengan Allah. Untuk itu setiap kali manusia tidak melakukan firman Allah yang diketahuinya secara konsisten, maka ia telah berdosa terhadap Allah. Untuk menyelesaikan dosa, manusia harus memiliki kerendahan hati untuk mengaku dosa di hadapan Allah agar memperoleh pengampunan dan penyucian, bukan karena perbaikan yang dilakukan manusia terhadap dirinya sendiri. Manusia dapat saja merubah tingkah lakunya, tetapi ia juga harus sadar bahwa ia telah melakukan kesalahan dan dosa dan membutuhkan pengampunan, penyucian, dan pemulihan dari Allah. Jika manusia tidak bersikap demikian maka ia tidak menghormati Allah yang adalah Pencipta dan

${ }^{107}$ Ibid., 616.

${ }^{108}$ Ibid., 620-621. 
Penyelamat, tetapi ia bertuhan pada dirinya sendiri. Sepanjang manusia bergantung pada dirinya sendiri untuk kesucian dan kesalehan dirinya maka ia bertuhan pada dirinya sendiri.

\section{Pragmatisme Menolak Wahyu adalah Penyataan Diri Allah}

Menurut pragmatisme, wahyu hanya untuk mistik karena tidak dapat dibuktikan berdasarkan pengalaman pribadi. Walaupun wahyu dipercayai berdasarkan pertimbangan yang benar, tetapi tidak dapat dikatakan sebagai kebenaran, jika tidak disertai dan dibuktikan dengan pengalaman pribadi (James). ${ }^{109}$

Penyataan bukan berasal dari Tuhan, tetapi hasil penemuan manusia melalui hubungan sosial dan masyarakat yang demokraris. Dalam masyarakat yang demokratis, dogma tidak diperlukan, karena setiap orang memiliki hak dan kebebasan untuk memecahkan masalah yang dialaminya. Kebebasan inilah yang memacu perkembangan ilmu pengetahuan (Dewey). ${ }^{110}$ Dengan demikian nilai kebenaran keagamaan bukanlah yang diwahyukan tetapi muncul dari keinginan, perasaan, dorongan, dan kebiasaan yang sesuai dengan watak manusia sebagai perpaduan faktor biologis dan sosial yang ada di dalam dirinya. ${ }^{111}$

Dalam kekristenan wahyu adalah penyataan diri Allah yang mutlak dan benar dengan sebutan wahyu umum, yaitu ciptaan alam semesta, wahyu khusus, yaitu firman Allah, dan kesempurnaan penyataan Allah terdapat di dalam diri Yesus Kristus, yaitu Firman yang menjadi Manusia (Yoh. 1:1-4, 14; 14:6). Dengan demikian penyataan dalam kekristenan bukan berasal dari manusia atau hasil upaya manusia dengan menggunakan metode ilmiah, tetapi diberikan atau dinyatakan oleh Allah kepada manusia sehingga manusia dapat mengenal Allah yang telah menciptakan dan menyelamatkannya. Karena wahyu adalah penyataan diri Allah di dalam firman-Nya, maka wahyu (firman) dalam ajaran Kristen adalah mutlak, benar, dan tidak berubah.

Penyataan Allah melalui firman-Nya yang tertulis, yang disebut Alkitab, akan menuntun orang yang merenungkannya kepada pengenalan akan Yesus Kristus sebagai Juruselamat. Kebenaran firman Allah (Alkitab) juga memiliki nilai kekal dan diperlukan oleh setiap manusia untuk kebaikan hidupnya.

Dalam kehidupan rohani, terjadi proses internalisasi kebenaran firman Tuhan yang dikerjakan oleh Roh Kudus. Roh Kudus bekerja secara intemal di dalam hidup manusia untuk mengingatkan semua

\footnotetext{
109 "William James"; diakses pada tanggal 16 Mei 2010; tersedia di http://en.wikipedia.org/wiki/William

${ }^{110}$ Boehlke, 2005, 617.

${ }^{111}$ Uyoh Sadulloh, 2007, 124.
} 
kebenaran agar manusia hidup di jalan yang benar (Yoh 14:26;16:8-1 l) dan menghasilkan buah Roh yaitu kasih, sukacita, damai sejahtera, kesabaran, kemurahan, kebaikan, kesetiaan, kelemahlembutan, dan penguasaan diri (Gal. 5:22-23).

Dengan demikian wahyu (firman) menyatakan Allah dan memiliki pengaruh spiritual sehingga manusia dapat memercayai Allah Tritunggal. Pengaruh dari penyataan-penyataan yang diberikan Allah kepada manusia membuat orang percaya tetap hidup dalam persekutuan dengan Allah dan hidup dalam damai sejahtera di dunia yang penuh dengan kerumitan permasalahan.

\section{KESIMPULAN}

Beberapa kesimpulan yang dapat dibuat berdasarkan konsep filsafat pragmatisme yang menekankan manfaat kebenaran perbuatan adalah:

\section{Filsafat Pragmatisme Mengandung Kebenaran Ateis}

Pemahaman tersebut dilandasi pada kberapakonsep pemikiran pragmatisme:

Pertama, Etika bukanlah apa yang benar, tetapi prilaku dan tujuan diri, dan tujuan hidup bersandar pada etika. Kedua, Keyakinan manusia terdapat pada manusia itu sendiri karena menjadi dasar baginya untuk melakukan yang benar, dan keyakinan dimulai dari proposisi yang dinilai benar. Cara yang dipakai untuk mencapai keyakinan adalah pertahanan diri, otoritas dan wibawa, akal, dan metode ilmiah. Ketiga, Kebenaran adalah pemeriksaan pemikiran dan pernyataan sesuai dengan hal yang sebenarnya yang memiliki fungsi untuk memberi kepuasan. Kebenaran adalah relatif karena setiap fakta baru akan memunculkan kebenaran baru yang pengujiannya melalui pembahasan diskusi. Keempat, Kebenaran yang menjadi tuntutan agama dapat ditemukan secara ilmiah. Kelima, Manusia memercayai bahwa kehendaknya bebas yang membebaskannya dari kekasaran, ketakutan, dan kematian, dan manusia harus diperbudak oleh kebebasannya. Keenam, Wahyu adalah mistik, tidak dapat diklaim sebagai kebenaran jika tanpa pengalaman pribadi. Ketujuh, Pengalaman manusia menjadi unsur penting untuk menentukan kebenaran dan metode digunakan untuk mencapai kebenaran yang terdapat dalam pengalaman. Pengalaman adalah tidak mutlak dan dapat 
berubah demikian pula sifat dari kebenaran adalah relatif. Kedelapan, Pengalaman spiritualis dan kesusilaan bukan hasil pembentukan secara keagamaan, tetapi pemberdayaan seluruh potensinya yang direalisasikan dalam masyarakat. Kesembilan, Penyataan bukanlah dari Tuhan, tetapi penemuan yang dilakukan manusia dan kebenaran supernatural tidak diakui karena masalah adikodrati. Kesepuluh, Kesalahan bukanlah dosa, tetapi ketidaksesuaian antara metode dengan akal. Kesebelas, Kebenaran keagamaan bukanlah sesuatu yang diwahyukan, tetapi muncul dari keinginan, dorongan, perasaan dan kebiasaan manusia.

Inti pengajaran filsafat pragmatisme tidak mengakui Allah Tritunggal, firman Allah, mujizat, wahyu, dan hal-hal yang supernatural dari Allah, tetapi hanya terfokus pada manusia. Dalam hal ini, filsafat pragmatisme adalah filsafat ateis yang menyusup melalui dunia filsafat, pendidikan, dan ilmu pengetahuan, yang membuat manusia adalah "allah" terhadap dirinya sendiri, sehingga menolak nilai-nilai religius dan hal-hal yang adikodrati tentang Allah Tritunggal, firman-Nya, kedaulatan kuasa-Nya atas segala yang telah diciptakan-Nya, dan pemberlakuan kuasa-Nya dalam kehidupan umat-Nya sehari-hari.

\section{Filsafat Pragmatisme Mengingatkan Gereja tentang Pemberdayaan Potensi Umat}

Walaupun kebenaran pragmatisme adalah kebenaran ateis, tetapi pemunculan pragmatisme sebagai gerakan filsafat yang menghargai manusia serta memberdayakan potensi yang dimilikinya. Beberapa penekanan filsafat pragmatisme yang mengacu kepada pemberdayaan potensi adalah: 1) penggunaan proses penelitian sebagai bagian dari kehidupan sehari-hari; 2) manusia memberdayakan dirinya dalam mengatur lindakannya untuk mengantisipasi peristiwa-peristiwa yang menghadangnya; 3) adanya kesepakatan dan mufakat bersama tentang pendapat dan pendirian untuk diterima secara umum; 4) keadaan suatu obyek adalah benar jika proposisi terhadap obyek tersebut sesrtai dengan kenyataan; 5) penggunaan bahasa untuk memahami orang lain dan memiliki kepekaan terhadap penderitaan orang lain.

Menyikapi konsep filsafat pragmatisme yang demikian menunjukkan bahwa kecenderungan filsafat pragmatisme adalah memberdayakan manusia dengan segala potensi yang dimiliki agar bermanfaaat bagi dirinya dan bagi orang lain. Pemahaman yang demikian menyadarkan gereja bahwa gereja tidak hanya memerhatikan hal-hal spiritual, supernatural, metafisis dalam pengajarannya, dan tetapi juga menaruh perhatian kepada keberadaan umat yang ada dengan segala pontensi yang dimilikinya. Gereja tidak hanya terfokus dan sibuk untuk 
mengurus hal-hal rohani umatnya" tetapi juga memiliki upaya untuk memberdayakan potensi pengetahuan, bakat, kemampuan kerja yang dimiliki umat agar berguna bagi dirinya dan orang lain.

Sebenarnya Alkitab berbicara tentang potensi orang percaya sebagai imamat yang rajani (Kel. 19:5-6; Yes. 61:6a; I Pet. 2:9), anggota tubuh Kristus dengan karuni rohani yang dimiliknya (Roma 12:3-8; I Kor. 12-14;Ef. 4:1 1), dan talenta (Mat 25:14-30). Untuk itu gereja harus mengoreksi filosofi pelayanannya, yang mana perwujudan dari melayani Tuhan adalah melayani sesamanya, dengan cara, menghargai sesamanya sebagai gambar dan rupa Allah yang telah dilengkapi dengan berbagai potensi serta memberdayakannya bagi Tuhan, dirinya, dan gereja.

Dengan demikian, dalam melaksanakan pelayanan dalam gereja lokal, gembala bukanlah seorang single fighter, tetapi pemimpin yang melengkapi jemaatnya dan bekerja sama dengan jemaat sebagai rekan pelayan untuk melaksanakan semua tanggung jawab pelayanan dalam gereja demi pembangunan tubuh Kristus (Ef. 4: I I - 1 6).

\section{Filsafat Pragmatisme Mengingatkan Gereja tentang Kebenaran Perbuatan}

Filsafat pragmatisme menekankan manfaat perbuatan manusia bagi dirinya sendiri sehingga memberinya hidup dan memberikan jalan keluar dari masalah yang dihadapinya. Selain itu, filsafat pragmatisme juga menekankan kebenaran yang diupayakan manusia untuk memberikan manfaat hidup baginya, dan dengan bahasa yang digunakan dan mempelajari karya sastra, dapat menimbulkan dan meningkatkan kepekaan seseorang terhadap penderitaan orang lain.

Menyikapi pengajaran filsafat pragmatisme yang demikian menunjukkan bahwa pragmatisme menolak Allah sebagai Pencipta, Penyelamat, dan Pemelihara yang memiliki kedaulatan penuh dalam kehidupan manusia untuk memberikannya hidup, ketentangan, dan kebahagian. Namun pada sisi lain filsafat pragmatisme menekankan kepedulian terhadap sesama.

Sebenarnya pemunculan konsep filsafat yang demikian menyadarkan gereja bahwa gereja tidak hanya mengajarkan umatnya tentang hal-hal adikodrati dengan penekanan "dibenarkan hanya oleh iman" yang dipahami secara sepihak, dan mengabaikan realita kehidupan jemaat sehari-hari bahwa "oleh perbuatanmu engkau akan dihakimi" atau "iman tanpa perbuatan adalah mati," sehingga orang Kristen kurang memiliki kepekaan terhadap perbuatan dirinya dan memiliki tanggung jawabnya terhadap sesamanya.

Memang benar bahwa oleh iman seorang dibenarkan dan diselamatkan, tetapi menjadi Kristen dan menjalani kehidupan Kristen yang benar, tidak hanya cukup pada posisi dibenarkan dan diselamatkan 
oleh iman, tetapi perbuatan seseorang dalam kehidupanya sehari-hari dan kepekaannya terhadap orang lain menjadi ukuran kehidupan rohaninya. Hal tersebut telah ditegaskan rasul Yakobus,

Apakah gunanya, saudara-saudaraku, jika seorang mengatakan, bahwa ia mempunyai iman, padahal ia tidak mempunyai perbuatan? Dapatkah iman itu menyelamatkan dia? Jika seorang saudara atau saudari tidak mempunyai pakaian dan kekurangan makanan sehari-hari, dan seorang dari antara kamu berkata: "Selamat jalan, kenakanlah kain panas dan makanlah sampai kenyang!", tetapi ia tidak memberikan kepadanya apa yang perlu bagi tubuhnya apakah gunanya itu? Demikian juga halnya dengan iman: Jika iman itu tidak disertai perbuatan, maka iman itu pada hakekatnya adalah mati. Tetapi mungkin ada orang berkata: "Padamu ada iman dan padaku ada perbuatan", aku akan menjawab dia: "Tunjukkanlah kepadaku imanmu itu tanpa perbuatan, dan aku akan menunjukkan kepadamu imanku dari perbuatan-perbuatanku." Engkau percaya, bahwa hanya ada satu Allah saja? Itu baik! Tetapi setan-setanpun juga percaya akan hal itu dan mereka gemetar. Hai manusia yang bebal, maukah engkau mengakui sekarang, bahwa iman tanpa adalah iman yang kosong? Bukankah Abraham, bapa kita dibenarkan karena perbuatanperbuatannya, ketika ia mempersembahkan Ishak, anaknya di atas mezbah? Kamu lihat bahwa iman bekerjasama dengan perbuatanperbuatan dan oleh perbuatanperbuatan itu iman menjadi sempurna. Dengan jalan demikian genaplah nas yang mengatakan: "Lalu percayalah Abraham kepada Allah, maka Allah memperhitungkan hal itu kepadanya sebagai kebenaran." Karena itu Abraham disebut: "Sahabat Allah." Jadi kamu lihat, bahwa manusia dibenarkan karena perbuatan-perbuatannya dan bukan hanya karena iman. Dan bukankah demikian juga Rahab, pelacur itu, dibenarkan karena perbuatan-perbualannya, ketika ia menyembunyikan orang-orang yang disuruh itu di dalam rumahnya lalu menolong mereka lolos melalui jalan yang lain? Sebab seperti tubuh tanpa roh adalah mati, demikian jugalah iman tanpa perbuatan-perbuatan adalah mati (Yak . 2:14-26). ${ }^{112}$

Rasul Yakobus memberikan kesaksian tentang pentingnya iman dan perbuatan berjalan bersama-sama dalam kehidupan orang percaya yang didasarkan pada contoh Abraham (Kej.15:6;22:1-14) dan Rahab

\footnotetext{
${ }^{112}$ Alkitab, LAI TB.
} 
(Yos. 2:1-22;3:9) untuk menunjukkan bahwa perbuatan orang percaya memiliki nilai kepercayaan di hadapan Allah.

Konsep tentang kebenaran perbuatanya sempat ditolak oleh Martin Luhter, tokoh reformasi gereja. Menurut Luther, manusia dibenarkan oleh iman seperti konsep yang dinyatakan rasul Paulus dalam surat Roma, bukan perbuatan. Pembenaran perbuatan dalam surat Yakobus dianggap sebagai oposisi terhadao konsep rasul Paulus, karena rasul Paulus menekankan iman, bukan perbuatan. Luther juga menolak surat Yakobus dalam pengkanonan Alkitab karena menekankan hukum dan perbuatan, bukan kasih dan anugerah. ${ }^{113}$ Bahkan menurut Luther, kitab Yakobus menimbulkan banyak masalah karena isinya mendukung ajaran paus yang menekankan perbuatan. ${ }^{114}$

Penentangan konsep rasul Yakobus yang dilakukan oleh Luther kelihatan menjadi pengajaran gereja sejak reformasi yang dilakukan oleh Luther. Gereja cenderung menekankan kebenaran iman dan mengabaikan kebenaran perbuatan. Tetapi sebenaranya Alkitab berbicara secara adil bahwa dengan iman seorang diselamatkan dan perbuatannya diperhitungkan sebagai kebenaran. Iman tanpa perbuatan adalah iman yang tidak berguna, baik bagi diri orang yang bersangkutan dan bugi orang lain. Untuk itu, iman perlu dinyatakan dan dibuktikan melalui perbuatan, karena "iman bekerja sama dengan perbuatan perbuatan dan oleh perbuatan-perbuatan itu iman menjadi sempurna" (ay. 22) untuk menegaskan pentingnya perbuatan. ${ }^{115}$

Dengan demikian, kunci hidup orang Kristen bukan hanya percaya atau bukan hanya berbuat tetapi percaya dan berbuat. Ia percaya kepada Allah Tritunggal dan melakukan tanggung jawabnya dalam kehidupannya sehari-hari sesuai dengan firman-Nya. Ia berbuat yang baik, benar, dan suci untuk dirinya dan orang lain sebagai bukti imannya kepada Allah Tritunggal yang telah menyelamatkan dan memeliharanya Dan pada akhirnya olehperbuatannyalah ia akan dihakimi oleh Pencipta dan Juruselamatnya.

\section{Filsafat Pragmatisme Mengingatkan Gereja tentang Active-Learner}

Walaupun dalam konsep Kristen, ada penolakan terhadap kebenaran yang tidak kekal dan berubah-ubah, dan juga menolak pendidikan yang seolah-olah menjadi juruselamat bagi manusia sehingga

\footnotetext{
${ }^{113}$ John Dillenberger (editor), Martin Luther: Selections from His Writings (Garden City: Double Day, 1961), 35-

36. Dikutip oleh Hasan Sutanto, Surat Yakobus: Berita yang Patut Didengar (Malang: Literatur SAAT, 2006),66-67.

${ }^{114}$ Lewis W. Spitz dan Helmut T. Lehmann (general editor), Luther's Works, Vol. 34 (Philadelphia: Muhlenberg Press, 1960), 317. Dikutip oleh Hasan Sutanto, 2006, 6

115 Sutanto, 207-208.
} 
filsafat pragmatisme dapat dianggap sebagai gerakan filsafat yang tidak mengenal Allah dan firman Allah, tetapi konsep active-learner sangat memengaruhi dunia pendidikan saat ini.

Dalam kehidupan Kristen diakui bahwa Allah berdaulat atas kehidupan manusia, bahkan, Allah sangat menghormati dan menghargai manusia ciptaan-Nya, sehingga Ia menjaga, memelihara serta menuntun umat mereka dalam kehidupan mereka sehari-hari. Allah memperlakukan umat-Nya sesuai dengan kapasitas, kemampuan, dan potensi yang dimiliki setiap orang. Untuk itu, dalam dunia Pendidikan Kristen, para pendidik harus menghormati hak para peserta didik, menerima kepribadian mereka sebagaimana adanya mereka, dan menghargai apapun latar belakang sosial mereka serta kemampuan intelektual mereka. Para pendidik tidak hanya memberikan atau mentransfer ilmu pengetahuan, tetapi juga harus memotivasi dan memfasilitasi peserta didik untuk menemukan dan mengembangkan segala kecerdasannya melalui partisipasi aktif siswa dalam proses belajar mengajar.

Selain itu, dalam proses belajar mengajar yang dilaksanakan di kelas dan di luar kelas, pengajaran-pengajaran Kristen tentang Allah, sorga dan kehidupan kekal, Yesus adalah Juruselamat, firman Allah adalah kebenaran yang mutlak tidak bersalah dan tidak keliru, Roh Kudus adalah Allah yang menyertai dan memimpin umat Allah kepada kebenaran, gereja adalah tubuh Kristus, dan menghormati negara dan pemerintah, haruslah mendapat penekanan penting dalam pengajaranpengajaran yang diberikan kepada para peserta didik.

Dalam dunia pendidikan teologi, prinsip active-learner juga seharusnya dipraktekkan oleh para pendidik, agar tidak terkesan bahwa pendidikan teologi identik dengan pengindoktrinasian. Dalam mempelajari doktrin, peserta didik perlu ditolong untuk terlibat secara aktif dalam menemukan pengajaran-pengajaran yang benar yang difasilitasi oleh pendidik. Ini dimaksudkan agar peserta didik memahami secara benar kebenaran yang diimaninya, menghidupinya, dan ia sendiri pun dapat mempertanggungiawabkannya apa yang diketahui dan dipercayainya kepada orang lain secara benar.

\section{KEPUSTAKAAN}

\section{Buku-buku}

Achmadi, Asmoro. Filsafat Umum. Jakarta: Rajawali Press, 2010.

Boehlke, Robert R. Sejarah Perkembangan Pikiran dan Praktek Pendidikan Agama Kristen. Jakarta: BPK Gunung Mulia, 2005. 
Dewey, John. "My Pedagogic Creed" dalam Robert Ulich, Three Thousand Years of Educational Wisdom Cambridge, MA: Harvard University, 1954.

Dewey, John. Reconstruction in Philosophy.Boston: Beacon, 1920.

Dillenberger, John (editor), Martin Luther: Selections from His Writings (Garden City: Double Day, 1961

Dykhuizen, George The Life and Mind of John Dewey. Carbondale and Edwardsville, Illinois: Southern Illinois University, 1973.

Khuza'i, Rodliyah. Dialog Epistemologi Mohammad Iqbal dan Charles S. Peirce. Bandung: Refika Aditama, 2007.

Hadiwijono, Harun. S ari Sejarah Filsafat Barat II. Yogyakarta :Kanisius, 2004.

Lintemann, Eta . Teologi Kontemporer: Ilmu atau Praduga? Malang: Institut Injil Indonesia, 1991.

M. Conn, Harvie. Teologia Kontemporer. Malang: Literatur SAAT, 2007.

Munitz, Milton K. Contemporary Analytic Philosphy. New York:Macmillan Publishing Company Inc., 1981.

Poedjawijatna,I. R., Pembimbing ke Arah Alam Filsafat. Jakarta: Bina Aksara, 1983.

Rorty, Richard. Phylosophy and the Miror of Nature. Oxford: Blackwell, 1980.

Sadulloh, Uyoh. Pengantar Filsafat Pendidikan. Bandung: Alfa Beta, 2007.

Spitz, Lewis W. dan Helmut T. Lehmann (general editor), Luther's Works, Vol. 34 Philadelphia: Muhlenberg Press, 1960.

Suparlan, Y. B. Aliran-Aliran Baru dalam Pendidikan. Yogyakarta: Andi Offset, 1984.

Sutanto, Hasan. Surat Yakobus: Berita yang Patut Didengar. Malang: Literatur SAAT, 2006.

Sutarman, T. "Dasar Teologi Kontemporer (Filsafat yang Menggunakan Akal)" materi pembelajaran Colloquium Theologiqum. Semarang: STT Baptis, 2010.

Zaluchu, Sonny E. "Perkembangan Teologi Kristen di Dekade Pertama Abad XXI" dalam T. Sutarman, Bunga Rampai Jenis-Jenis Teologi pada Periode 1990-2009.

Internet

Abdullah, Mohammad Najib. "Pragmatisme: Sebuah Tinjauan Sejarah Intelektual Amerika" diakses pada tanggal 11 Mei; tersedia di 2010.http://library.usu.ac.id/download/ts/sejarah-mohammad.pdf e-USU Repository 2004 
Amra, Leila. "Dekonstruksi Pragmatisme" diakses pada tanggal 10 Mei 2010; tersedia di http://www.gaulislam.com/dekonstruksipragmatisme dimuat tanggal 8 September 2007.

Concise Encyclopedia Britannica, s.v. "Charles Sanders Peirce" diakses pada tanggal 11 Mei 2010.;tersedia di

http://www.answer.com/topic/charles-pierce

Gunawan "Kajian Epistemologi Charles Sanders Pierce (1839-19140"

diakses pada tanggal 11 Mei 2010;tersedia

dihttp://grelovejogja.worpress.com/2008/12/18/kajian-

epistemologi-charles-sanders-pierce-1839-1914/ dimuat pada tanggal 18 Desember 2008.

Pragmatism diakses pada tanggal 11 Mei 2010; tersedia di http://plato.stanford.edu/entries/pragmatism/

Purwanto, Edi “Merentang Nalar Pragmatism" diakses pada tanggal llMei 2010; tersedia di http://jendelapemikiran.wordpress.com/2008/02/25/merentangnalar-pragamatisme. 